NBER WORKING PAPER SERIES

\title{
ESTIMATING THE PAYOFF TO ATTENDING \\ A MORE SELECTIVE COLLEGE: \\ AN APPLICATION OF SELECTION ON \\ OBSERVABLES AND UNOBSERVABLES
}

\author{
Stacy Berg Dale \\ Alan B. Krueger \\ Working Paper 7322 \\ http://www.nber.org/papers/w7322 \\ NATIONAL BUREAU OF ECONOMIC RESEARCH \\ 1050 Massachusetts Avenue \\ Cambridge, MA 02138 \\ August 1999
}

We thank Orley Ashenfelter, Marianne Bertrand, Bill Bowen, David Breneman, David Card, Jim Heckman, Bo Honore, Larry Katz, Deborah Peikes, Michael Rothschild, Sarah Turner, and colleagues at the Mellon foundation for helpful discussions. We alone are responsible for any errors in computation or interpretation that may remain despite their helpful advice. This paper makes use of the College and Beyond (C\&B) database. The C\&B database is a "restricted access database." Research who are interested in using this database may apply to the Andrew W. Mellon foundation for access. The views expressed herein are those of the authors and not necessarily those of the National Bureau of Economic Research.

(C) 1999 by Stacy Berg Dale and Alan B. Krueger. All rights reserved. Short sections of text, not to exceed 
two paragraphs, may be quoted without explicit permission provided that full credit, including $\odot$ notice, is given to the source.

Estimating the Payoff to Attending a More Selective College:

An Application of Selection on Observables and Unobservables

Stacy Berg Dale and Alan B. Krueger

NBER Working Paper No. 7322

August 1999

JEL No. J24

\section{$\underline{\text { ABSTRACT }}$}

There are many estimates of the effect of college quality on students' subsequent earnings. One difficulty interpreting past estimates, however, is that elite colleges admit students, in part, based on characteristics that are related to their earnings capacity. Since some of these characteristics are unobserved by researchers who later estimate wage equations, it is difficult to parse out the effect of attending a selective college from the students' pre-college characteristics. This paper uses information on the set of colleges at which students were accepted and rejected to remove the effect of unobserved characteristics that influence college admission. Specifically, we match students in the newly colleted College and Beyond (C\&B) Data Set who were admitted to and rejected from a similar set of institutions, and estimate fixed effects models. As another approach to adjust for selection bias, we control for the average SAT score of the schools to which students applied using both the C\&B and National Longitudinal Survey of the High School Class of 1972. We find that students who attended more selective colleges do not earn more than other students who were accepted and rejected by comparable schools but attended less selective colleges. However, the average tuition charged by the school is significantly related to the students' subsequent earnings. Indeed, we find a substantial internal rate of return from attending a more costly college. Lastly, the payoff to attending an elite college appears to be greater for students from more disadvantaged family backgrounds.

Stacy Berg Dale The Andrew W. Mellon Foundation 282 Alexander Road

Princeton, NJ 08540
Alan B. Krueger

Woodrow Wilson School

Princeton University

Princeton, NJ 08544

and NBER

akrueger@pucc.princeton.edu 
A burgeoning literature has addressed the question, "Does the 'quality' of the college that students attend influence their subsequent earnings?"1 Obtaining accurate estimates of the payoff to attending a higher quality undergraduate institution is of obvious importance to the parents of prospective students who foot the tuition bills, and to the students themselves. In addition, because college selectivity is typically measured by the average characteristics (e.g., average SAT score) of classmates, the literature is closely connected to theoretical and empirical studies of peer group effects on individual behavior. And with higher education making up 40 percent of total educational expenditures in the United States (see U.S. Department of Education, 1997; Table 33), understanding the impact of selective colleges on students' labor market outcomes is central for understanding the role of human capital. ${ }^{2}$

Past studies have found that students who attended colleges with higher average SAT scores or higher tuition tend to have higher earnings when they are observed in the labor market. Attending a college with a 100 point higher average SAT is associated with 3 to 7 percent higher earnings later in life (see, e.g., Kane, 1998). An obvious concern with this conclusion, however, is that students who attend more elite colleges may have greater earnings capacity regardless of where they attend school. Indeed, the very attributes that lead admissions committees to select certain applicants for admission may also be rewarded in the labor market. Most past studies have used Ordinary Least Squares (OLS) regression analysis to attempt to control for differences in student attributes that are correlated with earnings and college quality. But college admissions

\footnotetext{
${ }^{1}$ The modern literature began with papers by Hunt (1963), Solmon (1973), Wales (1973), Solmon and Wachtel (1975), and Wise (1975), and has undergone a recent renaissance, with papers by Brewer and Ehrenberg (1996), Behrman et al. (1996), Daniel (1997), Kane (1998), and others. See Brewer and Ehrenberg (1996; Table 1) for an excellent summary of the literature.

${ }^{2}$ This figure ignores any earnings students forego while attending school, which would increase the relative cost of higher education.
} 
decisions are based in part on student characteristics that are unobserved by researchers and therefore not held constant in the estimated wage equations; if these unobserved characteristics are positively correlated with wages, then OLS estimates will overstate the payoff to attending a selective school. Only three previous papers that we are aware of have attempted to adjust for selection on unobserved variables in estimating the payoff to attending an elite college. Brewer and Ehrenberg (1996) use a parametric utility maximizing framework to model students' choice of schools, under the assumption that all students can attend any school they desire. Behrman, Rosenzweig and Taubman (1996) utilize data on female twins to difference out common unobserved effects. And Berhman, et al. (1996) use family variables to instrument for college choice. Our paper complements these previous approaches.

This paper employs two new approaches to adjust for nonrandom selection of students on the part of elite colleges. In one approach, we only compare college quality and earnings among students who were accepted and rejected by a comparable set of colleges, and are comparable in terms of observable variables. In the second approach, we hold constant the average SAT score of the schools to which each student applied, as well as the average SAT score of the school the student attended, the student's SAT score, and other variables. The second approach is nested in the first estimator. Conditions under which these estimators provide unbiased estimates of the payoff to college quality are discussed in the next section. In short, if admission to a college is based on a set of variables that are observed by the admissions committee and later by the econometrician (e.g., student SAT), and another set of variables that is observed by the admissions committee (e.g., an assessment of student motivation) but not by the econometrician, and if both sets of variables influence earnings, then looking within matched sets of students who were accepted and rejected by 
the same groups of colleges can help overcome selection bias.

Barnow, Goldberger and Cain (1981) point out that, "Unbiasedness is attainable when the variables that determined the assignment rule are known, quantified, and included in the [regression] equation." Our first estimator extends the concept of "selection on the observables" to "selection on the observables and unobservables," since information on the unobservables can be inferred from the outcomes of independent admission decisions by the schools the student applied to. The general idea of using information reflected in the outcome of independent screens to control for selection bias may have applications to other estimation problems, such as estimating wage differentials associated with working in different industries or sizes of firms (where hiring decisions during the job search process provide screens) and racial differences in mortgage defaults (where denials or acceptances of applications for loans provide screens). ${ }^{3}$

We provide selection-corrected estimates of the payoff to school quality using the College and Beyond dataset, which was recently collected by the Andrew W. Mellon Foundation and analyzed extensively in Bowen and Bok (1992), and the National Longitudinal Survey of the High School Class of 1972 (NLS-72). We examine the effect on earnings of several school quality indicators, including selectivity (as measured by the school's average SAT score) and net tuition. Our primary finding is that the financial return to attending a higher quality college falls considerably once we adjust for selection on the part of the college. Nonetheless, we still find a substantial payoff to attending schools with higher net tuition. Finally, we examine the impact of attending a more selective college on students' grades, graduation rates, and post-college

\footnotetext{
${ }^{3}$ Braun and Szatrowksi (1984) use a related idea to evaluate law school grades across institutions by comparing the performance of students who were accepted at a common set of law schools but attended different schools.
} 
educational attainment.

\section{Simulation of Admissions, College Attendance and Earnings}

For most students, college attendance involves three sequential choices. First, a student decides which set of colleges to apply to for admission. Second, colleges independently decide whether to admit the student to their schools. Third, the student and her parents decide which college the student will attend from the subset of colleges that admitted her.

We begin by assuming that colleges determine admissions decisions by weighing various attributes of the student. Indeed, a recent survey by the National Association for College Admission Counseling indicates that admissions officers consider many factors when selecting students, including not only students' high school grades and test scores, but also factors such as their essays, counselor and teacher recommendations, community service, and extracurricular activities (NACAC Bulletin, November, 1998). Next, we assume that each college uses a threshold to make admissions decisions. An applicant who possesses characteristics that place him or her above the college's threshold is accepted; if not, he or she is rejected. Additionally, luck may enter into the admission decision.

To proceed analytically, we partition the characteristics that the admissions committee observes into two sets of variables: a set that is subsequently observable by researchers, denoted $\mathrm{X}_{1}$, and a set that is unobservable by researchers, denoted $\mathrm{X}_{2}$. The observable set of characteristics could include factors such as the student's SAT score and high school grade point average (GPA), whereas the unobservable set could include factors such as assessments of the student's motivation, ambition and maturity as reflected in her essay, college interview and letters of recommendation. 
Without loss of generality, assume that $\mathrm{X}_{1}$ and $\mathrm{X}_{2}$ are scalar variables. We assume a linear admission rule, in which $X_{1}$ and $X_{2}$ have been scaled accordingly. In particular, we assume college $\mathrm{j}$ uses the following rule to admit or reject applicant i:

(1) if $Z_{i j}=X_{1 i}+X_{2 i}+e_{i j}>C_{j}$ then admit to college $j$

otherwise reject applicant at college $\mathrm{j}$

where $Z_{\mathrm{ij}}$ is the latent quality of the student as judged by the admission committee, $\mathrm{e}_{\mathrm{ij}}$ represents the idiosyncratic views of college $\mathrm{j}$ 's admission committee, and $\mathrm{C}_{\mathrm{j}}$ is the cutoff quality level the college uses for admission. ${ }^{4}$ The term $\mathrm{e}_{\mathrm{ij}}$ represents luck and idiosyncratic factors that affect admission decisions but are unrelated to earnings. We assume $e_{i j}$ is independent across colleges. By definition, more selective colleges have higher values of $\mathrm{C}_{\mathrm{j}}$.

Now suppose the "structural earnings function" relating income to the students' attributes is:

(2) $\ln W_{i}=\beta_{0}+\beta_{1} S T_{j *}+\beta_{2} X_{1 i}+\beta_{3} X_{2 i}+\varepsilon_{i}$

where $\mathrm{SAT}_{\mathrm{j}^{*}}$ is the average SAT score of matriculants at the college student $\mathrm{i}$ attended, $\mathrm{X}_{1}$ and $\mathrm{X}_{2}$ are the two sets of characteristics used by the admission committee to determine admission, and $\varepsilon_{\mathrm{i}}$ is an idiosyncratic error term that is uncorrelated with the other variables on the right hand side of (2). Since individual SAT scores are a common $\mathrm{X}_{1}$ variable, $\mathrm{SAT}_{\mathrm{j}^{*}}$ can be thought of as the mean of $X_{1}$ taken over students who attend college $j^{*}$. The parameter $\beta_{1}$, which may or may not equal zero, represents the monetary payoff to attending a more selective college.

In practice, researchers have been forced to estimate a wage equation that omits $\mathrm{X}_{2}$ :

(3) $\ln \mathrm{W}_{\mathrm{i}}=\beta_{0}^{\prime}+\beta_{1}^{\prime} \mathrm{SAT}_{\mathrm{j}^{*}}+\beta_{2}^{\prime} \mathrm{X}_{\mathrm{li}}+\mathrm{u}_{\mathrm{i}}$

${ }^{4}$ We ignore the possibility of wait listing the student. 
Even if students randomly select the college they attend from the set of colleges that admitted them, estimation of (3) will yield biased and inconsistent parameter estimates of $\beta_{1}$ and $\beta_{2}$. Most importantly for our purposes, if students choose their school randomly from their set of options, the payoff to attending a selective school will be biased upward because students with higher values of the omitted variable, $\mathrm{X}_{2}$, are more likely to be admitted to, and therefore attend, highly selective schools. Since the labor market rewards $\mathrm{X}_{2}$, and school-average SAT and $\mathrm{X}_{2}$ are positively correlated, the coefficient on school-average SAT will be biased upward. The coefficient on $\mathrm{X}_{1}$ can be positively or negatively biased, depending on the relationship between $X_{1}$ and $X_{2}$. Also notice that the greater the correlation between $X_{1}$ and $X_{2}$, the lesser the bias in $\beta_{1}^{\prime}{ }^{5}$

Formally, the coefficient on school-average SAT score is biased upward in this situation because $E\left(\ln W_{i} \mid \operatorname{SAT}_{j^{*}}, X_{1 i}\right)=\beta_{0}+\beta_{1} \operatorname{SAT}_{j^{*}}+\beta_{2} X_{1 i}+E\left(u_{i} \mid X_{1 i}+X_{2 i}+e_{i^{*}}>C_{j^{*}}\right)$. The expected value of the error term $\left(\mathrm{u}_{\mathrm{i}}\right)$ is higher for students who were admitted to, and therefore more likely to attend, more selective schools. ${ }^{6}$

If, conditional on gaining admission, students choose to attend schools for reasons that are independent of $\mathrm{X}_{2}$ and $\varepsilon$, then students who were accepted and rejected by the same set of schools would have the same expected value of $u_{i}$. Consequently, our proposed solution to the school selection problem is to include an unrestricted set of dummy variables indicating groups of students who received the same admissions decisions (i.e., the same combination of acceptances and rejections) from the same set of colleges. Including these dummy variables absorbs the conditional

\footnotetext{
${ }^{5}$ This should be intuitively clear from considering a situation in which $X_{1}$ and $X_{2}$ are perfectly correlated. In this case, the school average SAT is unaffected by the omitted $X_{2}$, although the coefficient on $X_{1}$ confounds the effect of $X_{1}$ and $\mathrm{X}_{2}$.

${ }^{6} \mathrm{~A}$ classic reference on selection bias is Heckman (1979).
} 
expectation of the error term if students randomly choose to attend a school from the set of schools that admitted them. Moreover, even if college matriculation decisions (conditional on acceptance) are related to $\mathrm{X}_{2}$, controlling for dummies indicating whether students were accepted and rejected by the same sets of schools absorbs some of the effect of the unobserved $\mathrm{X}_{2}$.

To see why controlling for dummies indicating acceptance and rejection at a common set of schools partially controls for the effect of $\mathrm{X}_{2}$, consider two colleges that a subset of students applied to with admission thresholds $\mathrm{C}_{1}<\mathrm{C}_{2}$. In other words, college 2 is more selective than college 1 . If the selection rule in equation (1) did not depend on a random factor, then it would be unambiguous that students who were admitted to college 1 and rejected by college 2 possessed characteristics such that $C_{1}<X_{1}+X_{2}<C_{2}$. As $C_{1}$ approaches $C_{2}$, the sum of the students' observed and unobserved characteristics becomes uniquely identified by observations on acceptance and rejection decisions. ${ }^{7}$ If enough accept and reject decisions over a fine enough range of college selectivity levels are observed, then students with a similar history of acceptances and rejections will possess essentially the same average value of the observed and unobserved traits used by colleges to make admission decisions. Thus, even if matriculation decisions are dependent on $\mathrm{X}_{2}$, we can at least partially control for $\mathrm{X}_{2}$ by grouping together students who were admitted to and rejected by the same set of colleges and including dummy variables indicating each of these groups in the wage regression. Notice that to apply this estimator, it is necessary for students to be accepted by a diverse set of schools and for some of those students to attend the less selective colleges and others the more selective colleges from their menu of choices.

\footnotetext{
${ }^{7}$ The fact that idiosyncratic factors affect colleges' admissions decisions through $\mathrm{e}_{\mathrm{iij}}$ complicates, but does not distort, the inference that students who have been accepted and rejected by the same schools have similar values of $X_{1}+X_{2}$.
} 
The following simulations illustrate these points, and suggest that information on a relatively small number of college application outcomes is sufficient to reduce or eliminate the bias caused by unobserved variables that influence college admission decisions. For a sample of 4,000 observations, we simulated data as follows. We assume $\mathrm{X}_{\mathrm{li}}, \mathrm{X}_{2 \mathrm{i}}$ and $\mathrm{e}_{\mathrm{ij}}$ are standard normal, independently distributed variables. Every student applies to the same four colleges, and each college has a different value of $C_{j}$. The values of $C_{j}$ are set so that the most selective college admits approximately the top 12 percent of applicants, the second most selective college admits the top 50 percent, the third most selective college admits the top 70 percent, and the least selective college admits all applicants. A randomly selected quarter of students choose to attend the best school they were admitted to, and the remaining students randomly select which college to attend from among the ones that admitted them. ${ }^{8}$ We calculate each college's average SAT score by averaging over $\mathrm{X}_{1}$ for the students who attend the college. This acceptance and matriculation process naturally leads more selective colleges to have higher average SAT scores. We assume the structural wage equation specified in (2), and set $\beta_{1}=0$ and $\beta_{0}=\beta_{2}=\beta_{3}=0.5$ and draw $\varepsilon_{\mathrm{i}}$ from a standard normal distribution.

Panel A of Table 1 reports average regression statistics from 100 simulations of this model. As one would expect from the initial assumptions, a regression of $\ln W$ on SAT, $X_{1}$ and $X_{2}$ yields a coefficient of virtually 0 on school-average SAT (see column 1). If we omit $\mathrm{X}_{2}$ from the model, however, the coefficient on school-average SAT averages .58 in the simulations, and the coefficient

\footnotetext{
${ }^{8}$ Random selection of colleges on the part of students is obviously an unreasonable assumption, but as mentioned, for our selection correction to work all that is required is that the choice of college is independent of the error term in wage equation (2) and of $\mathrm{X}_{2}$.
} 
on $X_{1}$ falls to .42 (see column 2). ${ }^{9}$ In column 3 we implement our selection correction method. That is, we create 16 dummy variables indicating possible combinations of acceptances and rejections at the 4 schools, and include 15 of these dummies as explanatory variables. ${ }^{10}$ Including these dummy variables drives the coefficient on the school-average SAT score toward 0 . Note also that the coefficient on $\mathrm{X}_{1}$ falls to .26 when the admit/reject dummies are included. This occurs because $X_{1}+X_{2}$ is only controlled imperfectly by the accept/reject dummies, so $X_{1}$ still has some independent explanatory power. ${ }^{11}$ Consequently, it is inappropriate to interpret the coefficient on $\mathrm{X}_{1}$ as a structural parameter in the selection-corrected model, even though the estimate of $\beta_{1}$ is unbiased.

If the admission rule used by colleges depended only on $X_{1}$, and if $X_{1}$ were included in the wage equation, we would have a case of "selection on the observables" (see Barnow, Cain and Goldberger, 1981). In this case, however, we have "selection on the observables and unobservables" since $\mathrm{X}_{2 \mathrm{i}}$ and $\mathrm{e}_{\mathrm{ij}}$ are also inputs into admissions decisions. Nonetheless, as we have shown, we can control for the bias due to selective admissions by controlling for the groups of schools at which students were accepted and rejected.

The selection correction works well in this simulation because, conditional on being

\footnotetext{
${ }^{9}$ The coefficient on $X_{1}$ falls because $X_{1}$ and SAT are positively correlated. Since SAT is positively correlated with $X_{2}$ and $X_{1}$ is uncorrelated with $X_{2}$, the coefficient on SAT is biased up, which in turn causes the coefficient on $X_{1}$ to be biased down. If $X_{1}$ and $X_{2}$ are positively correlated, however, the effect of $X_{1}$ could be biased upward.

${ }^{10}$ In practice, fewer than 15 dummies were often used because some of the cells were empty. That is, in spite of the random factor in admissions, there were no simulated students who were rejected by some combination of schools and accepted by others.

${ }^{11}$ If we control for $X_{1}$ and the latent variable $\bar{Z}=X_{1}+X_{2}+\Sigma e_{j} / 4$ instead of the college application dummies, then the expected coefficient on $X_{1}$ still exceeds zero because the coefficient on $\bar{Z}$ is less than .5 due to idiosyncratic errors in evaluating the candidates. The accept/reject dummies are also imperfect measures of $X_{1}+X_{2}$, which is why $X_{1}$ has a coefficient that exceeds zero in column 3 .
} 
accepted, the average SAT score of the school students attend is uncorrelated with the students' personal characteristics. Indeed, column 4 shows that including three dummy variables indicating whether a student was admitted to each college has the same effect on the school SAT variable as controlling for the 16 possible configurations of rejections and acceptances among the 4 schools.

In reality, all students do not apply to the same set of colleges, and it is probably unreasonable to model students as randomly selecting the school they attend. A complete model of the two-sided selection that takes place between students and colleges is beyond the scope of the current paper, but it should be stressed that our selection correction still provides an unbiased estimate of $\beta_{1}$ if students' school enrollment decisions are a function of $X_{1}$ or any variable outside the model. The critical assumption is that students' enrollment decisions are uncorrelated with the error term of equation (2) and $\mathrm{X}_{2}$. If the decision rule students use to choose the college they attend from their set of options is related to their value of $X_{2}$, then the bias in the within-matched applicant model depends on the coefficient from a hypothetical regression of the average SAT score of the school the student attends on $\mathrm{X}_{2}$, conditional on $\mathrm{X}_{1}$ and the accept/reject dummies. It is possible that selection bias could be exacerbated by controlling for matched applicant effects. Griliches (1979) makes this point in reference to twins models of earnings and education. In the current context, however, if students apply to a fine enough range of colleges, the accept/reject dummies would control for $\mathrm{X}_{2}$, and the within-matched applicant estimates would be unbiased even if college choice on the part of students depended on $\mathrm{X}_{2}$. In the following simulation, we assume both application and matriculation decisions are related to $\mathrm{X}_{2}$. Under these conditions, compared to estimating equation (3), the proposed selection correction still yields a less biased estimate of $\beta_{1}$.

We alter the previous simulation in two respects. First, we assume that the bottom 40 
percent of students (in terms of $\mathrm{X}_{1}+\mathrm{X}_{2}$ ) only apply to the two least selective schools; the other students apply to all four schools. Second, we assume that more qualified students are more likely to attend the most selective school from the set of schools that admitted them. To accomplish this, we again assume that 25 percent of the students choose to attend the best college that admitted them, but for this simulation, we randomly select this 25 percent from the top half of the applicant pool (i.e., those students with $X_{1}+X_{2}>0$ ). All of the other students (which includes the bottom 40 percent of students who applied to two schools and the next 10 percent who applied to four) randomly choose which school to attend from the set that admitted them. Panel B provides results from simulating such a model 100 times. Although school-average SAT has a positive effect on earnings in all the models that omit $\mathrm{X}_{2}$, it is less than half as large when we include 17 dummies indicating the configurations of acceptances and rejections for the students who applied to the same set of schools. ${ }^{12}$ Also notice that in this simulation, the effect of school-average SAT is smaller in the model that controls for the 17 accept/reject configurations than in the model that includes 3 dummies indicating acceptance at each college.

Another factor that would be expected to influence student matriculation decisions is financial aid. By definition, merit aid is related to the school's assessment of the student's potential. Past studies have found that students are more likely to matriculate to schools that provide them with more generous financial aid packages (see, e.g., van der Klaauw, 1997). If more selective colleges provide more merit aid, the estimated effect of attending an elite college will be biased upward because relatively more students with higher values of $\mathrm{X}_{2}$ will matriculate at elite colleges,

\footnotetext{
${ }^{12}$ There are 2 more dummy variables in this simulation than in the previous simulation because there are two more combinations of acceptances and rejections representing the students that apply to only two schools.
} 
even conditional on the outcomes of the applications to other colleges. The relationship between aid and school selectivity is likely to be quite complicated, however. Breneman (1994; Chapter 3), for example, finds that the middle ranked liberal arts colleges provide more financial aid than the highest ranked and lowest ranked liberal arts colleges. If students with higher values of $X_{2}$ are more likely to attend less selective colleges because of financial aid, the selectivity bias could be negative instead of positive.

Also notice that if students choose the college they attend based on $\varepsilon$, the error in the structural wage equation, then the selection-bias adjustment could lead to more or less biased estimates. The bias would depend on the coefficient on SAT from a hypothetical regression of $\varepsilon$ on SAT, $\mathrm{X}_{1}$, and the accept/reject dummies.

Finally, an alternative though related approach to modelling unobserved student selection is to assume that students are knowledgeable about their academic potential, and reveal their potential ability by the choice of schools they apply to. Indeed, students may have a better sense of their potential ability than college admissions committees. To cite one prominent example, note that Steven Spielberg was rejected by both USC and UCLA film schools (Grover, 1998). It is plausible that students with greater observed and unobserved ability are more likely to apply to more selective colleges. In this situation, the error term in equation (3) could be modelled as a function of the average SAT score (denoted AVG) of the schools to which the student applied: $u_{i}=\tau_{0}+$ $\tau_{1} A V G_{i}+v_{i}$. If $v_{i}$ is uncorrelated with the SAT score of the school the student attended, we can solve the selection problem by including AVG in the wage equation. When we implement this approach, we also include dummy variables indicating the number of schools the students applied to. We call this approach the "self-revelation" model because individuals reveal their unobserved 
quality by their college application behavior. Notice also that the average SAT score of the schools the student applied to, and the number of applications they submitted, would be absorbed by including unrestricted dummies indicating students who were accepted and rejected by the same sets of schools; therefore, the self-revelation model is a special case of our first selection correction model.

\section{Data and Comparison to Previous Literature}

The College and Beyond (C\&B) Survey is described in detail in Bowen and Bok (1998, Appendix A). In short, the starting point for the $\mathrm{C} \& \mathrm{~B}$ database was the institutional records of students who enrolled in (but did not necessarily graduate from) one of 34 colleges in 1951, 1976 and 1989. These institutional records were linked to a survey administered by Mathematica Policy Research, Inc. for the Andrew W. Mellon Foundation in 1995-97 and to files provided by the College Entrance Examination Board (CEEB) and the Higher Education Research Institute (HERI) at the University of California, Los Angeles. We focus here on the 1976 entering cohort. While survey data are available for 23,572 students from this cohort, we exclude students from four historically black colleges and universities, and for most of our analysis we restrict the sample to those who were working full time. The 30 colleges and universities in our sample, as well as their average SAT scores and tuition, are listed in Appendix Table A. Our final sample consists of 14,239 full-time, full-year workers.

The C\&B institutional file consists of information drawn from students' applications and transcripts, including variables such as students' GPA, major and SAT scores. These data were collected for all matriculants at the C\&B private schools; for the four public universities, however, 
data were collected for a subsample of students, consisting of all known minority students, all varsity letter-winners, all students with combined SAT scores of 1,350 and above, and a random sample of all other students. We developed weights so that the sample is nationally representative of public and private universities and liberal arts colleges. ${ }^{13}$

The C\&B institutional data were linked to files provided by HERI and CEEB. The CEEB file contains information from the Student Descriptive Questionnaire (SDQ), which students fill out when they take the SAT exam. We use students' responses to the SDQ to determine their high school class rank and parental income. The file that HERI provided is based on data from a questionnaire administered to college freshman by the Cooperative Institutional Research Program (CIRP). We use this file to supplement $\mathrm{C} \& \mathrm{~B}$ data on parental occupation and education.

Finally, the $C \& B$ survey data consist of the responses to a questionnaire that most respondents completed by mail in 1996, although those who did not respond to two different mailings were surveyed over the phone. The survey response rate was approximately 80 percent. The survey data include information on 1995 annual earnings, occupation, demographics, education, civic activities, and satisfaction. ${ }^{14}$ Importantly for our purposes, early in the questionnaire respondents were asked, "In rough order of preference, please list the other schools

\footnotetext{
${ }^{13}$ We use Carnegie Classifications to define these categories. The public and private universities include all Doctorate-Granting Institutions (Research I and II and Doctorate I and II), and the liberal arts colleges include the Liberal Arts Colleges I.

${ }^{14}$ The C\&B survey asked respondents to report their 1995 pre-tax annual earnings in one of the following ten intervals: less than $\$ 1,000 ; \$ 1,000-\$ 9,999 ; \$ 10,000-\$ 19,999 ; \$ 20,000-\$ 29,999 ; \$ 30,000-\$ 49,999 ; \$ 50,000-74,999 ; \$ 75,000$ 100,$000 ; \$ 100,000-\$ 149,999 ; \$ 150,000-\$ 199,999$, and more than $\$ 200,000$. We converted the lowest nine earnings categories to a cardinal scale by assigning values equal to the midpoint of each range, and then calculated the natural $\log$ of earnings. For workers in the topcoded category, we used the 1990 Census (after adjusting the Census data to 1995 dollars) to calculate mean log earnings for college graduates age 36-38 who earned more than $\$ 200,000$ per year.
} 
you seriously considered."15 Respondents were then asked whether they applied to, and were accepted by, each of the schools they listed. ${ }^{16}$ By linking the school identifiers to a file provided by HERI, we determined the average SAT score of each school that each student applied to. This information enabled us to form groups of students who applied to a similar set of schools and received the same admissions decisions (i.e., the same combination of acceptances and rejections). Because there were so many colleges to which students applied, we considered schools equivalent if their average SAT score fell into the same 25 point interval. For example, if two schools had an average SAT score between 1200 and 1225, we assumed they used the same admissions cutoff. Then we formed groups of students who applied to, and were accepted and rejected by, "equivalent" schools. ${ }^{17}$

Table 2 illustrates how we would construct 5 groups of matched applicants for 15 hypothetical students. Students A and B applied to the exact same three schools and were accepted and rejected by the same schools, so they were paired together. The four schools to which students $\mathrm{C}, \mathrm{D}$, and $\mathrm{E}$ applied were sufficiently close in terms of average SAT scores that they were considered to use the same admission standards; because these students received the same

\footnotetext{
${ }^{15}$ Students who responded to the C\&B pilot survey were not asked this question, and therefore are excluded from our analysis.

${ }^{16}$ Students could have responded that they couldn't recall applying or being accepted, as well as yes or no. They were
asked to list three colleges other than the one they attended that they seriously considered. In addition, prior to the
question on schools the student seriously considered, respondents were asked "which school did you most want to
attend, that is, what was your first choice school?" If that school was different from the school the student attended,
there was a follow-up question that asked whether the student applied to their first-choice school, and whether they
were accepted there. Consequently, information was collected on a maximum of 4 colleges to which the student could
have applied, in addition to the college the student attended.
}

${ }^{17}$ Students who applied to only one school were not included in these matches. 
admissions decisions from comparable schools, they were categorized as matched applicants. Students were not matched if they applied to only one school (students F and G), or if no other student applied to a set of schools with similar SAT scores (student O). Five dummy variables would be created indicating each of the matched sets.

Table 3 provides weighted means and standard deviations for men and women in the sample who were employed full time in 1995. Everyone in the sample attended a C\&B school as a freshman but did not necessarily graduate from the school (or from any school). Nearly 70 percent of students in the unweighted data listed at least one other school they applied to in addition to the school they attended, whereas just over half of the students in the weighted sample reported applying to at least one additional school. This difference stems from the fact that students from public universities receive much more weight in the weighted sample than unweighted sample, and students who attended public universities were less likely to report applying to another school that they seriously considered attending. Among students who were accepted by more than one school, 59 percent chose to attend the most selective school to which they were admitted. We were able to match 44 percent of the students with at least one other student in the sample on the basis of the schools that they were accepted and rejected by. Summary statistics are also reported for the subsample of matched applicants. It is clear that the $\mathrm{C} \& \mathrm{~B}$ sample is very selective. The mean annual earnings in 1995 for full-time, full-year workers is $\$ 89,026$ for the male sample and $\$ 76,859$ for the pooled sample of men and women, both of which are high even for college graduates. The students' average SAT score (Math plus Verbal) exceeds 1,100. Nearly 40 percent of the sample was ranked in the top 10 percent of their high school class.

Because the schools included in the C\&B sample are highly selective, with average SAT 
scores ranging from 1,020 to 1,360 , we first compared the payoff to attending a more selective school in the $\mathrm{C} \& \mathrm{~B}$ sample to corresponding estimates from representative national samples of college graduates. In Table 4 we replicate as closely as possible the wage regressions reported by Kane (1998) and Daniel, Black and Smith (1997). Kane analyzes a pooled sample of men and women from the High School and Beyond (HSB) Survey, whereas Daniel, et al. use a sample of men from the National Longitudinal Survey of Youth (NLSY). In both studies, college selectivity is measured by the average SAT of students who attend each college, as reported by the institution. ${ }^{18}$ These estimates indicate that attending a school with a 100 point higher average SAT score is associated with 5 to 8 percent higher earnings later in life, but the estimates based on the C\&B survey are slightly higher than the corresponding estimates from the NLSY and especially the HSB. Brewer, Eide and Ehrenberg (1999) provide evidence that the payoff to attending an elite college increased between 1986 and 1992, which could account for the larger C\&B estimates. In the next section, we examine whether these estimates are confounded by unobserved student attributes.

\section{The Effect of College Selectivity on Earnings}

Tables $5 \mathrm{a}$ and $5 \mathrm{~b}$ present our main set of log-earnings regressions. We limit the sample to full-time, full-year workers, and estimate separate Weighted Least Squares (WLS) regressions for a

\footnotetext{
${ }^{18}$ For the C\&B survey, we based school-average SAT scores on a data file provided by HERI. HERI collects SAT score data from college guidebooks; the scores in the guidebooks are generally based on the schools' responses to surveys. The correlation between the HERI SAT scores and the school averages calculated from the students in the C\&B database for 30 schools is .94. The mean, however, is 25 points higher in the HERI data. We use the HERI data to be comparable with the previous literature (e.g., Kane, 1998), and because we do not have data on average SAT scores for schools outside the C\&B universe.
} 
pooled sample of men and women (Table 5a), and for the subset of men (Table 5b). ${ }^{19}$ The reported standard errors are robust to correlation in the errors among students who attended the same college. With the exception of a dummy variable indicating whether the student participated on a varsity athletic team, the explanatory variables are all determined prior to the time the student entered college. Most of the covariates are fairly standard, although an explanation of the "predicted log parental income" variable is necessary. Parental income was missing for many individuals in the sample. Consequently, we predicted income by first regressing log parental income on mother's and father's education and occupation for the subset of students with available family income data (see Appendix Table 2), and then multiplying the coefficients from this regression by the values of the explanatory variables for every student in the sample.

The basic model, reported in the first column of Tables $5 \mathrm{a}$ and $5 \mathrm{~b}$, is comparable to the models estimated in much of the previous literature in that no attempt is made to adjust for selective admissions. In Table 5a, the basic model indicates that students who attended a school with a 100 point higher average SAT score earned about 6 percent higher earnings in 1995, holding constant their own SAT score, race, gender, parental income, athletic status, and high school rank. For the sample of men in Table 5b, the basic model shows that the effect of a 100 point higher schoolaverage SAT score on earnings is similar, about 7 percent.

Column 2 presents the "matched applicant" model, which adjusts for selection by including dummy variables that indicate students who were accepted and rejected by the same sets of schools. As mentioned earlier, to form these groups we treat schools with average SAT scores in the same 25 point range as identical. We were able to match 6,335 students with at least one other student

\footnotetext{
${ }^{19}$ The sample of women was too small to draw precise estimates from, but the results were qualitatively similar.
} 
who applied to, and was accepted and rejected by, an equivalent set of institutions. Including dummies for the sets of matched students renders the effect of school-average SAT indistinguishable from zero in column 2 for both of the samples. The standard error doubles when we look within matched sets of students, but for the pooled sample, we can reject an effect of around 3 percent higher earnings for a 100 point increase in the school-average SAT score; that is, we can reject an effect size that is smaller than that found in most of the previous literature. The weaker effect of school SAT in the matched applicant models is not just a result of idiosyncracies of the restrictive matched applicant samples; if we estimate the basic model in column 1 for the matched applicant subsample, the results are qualitatively similar to those from the full sample.

Figure 1 illustrates the college application and attendance patterns of the most common sets of matched applicants (i.e., those sets that include at least 15 students). The length of the bars indicates the range of schools to which each set of matched students applied, and the shaded area of each bar represents the range of schools that each set of students actually attended. As shown by the figure; most students reported applying to a relatively narrow range of schools insofar as SAT scores are concerned, ${ }^{20}$ and the range of schools that students attended is even narrower. The average range of school-average SAT scores of students who were accepted by at least two schools was 139 points. ${ }^{21}$ Furthermore, dummies indicating the groups of matched students account for 85 percent of the variability of in the average SAT scores of the schools the students actually attended.

\footnotetext{
${ }^{20}$ It is possible that the range of schools is particularly circumscribed because the C\&B survey asked respondents to report the schools they "seriously considered."

${ }^{21}$ This figure refers to the average range of school-SAT scores for the schools that accepted the students. The average range of school-average SAT scores for the schools that students applied to (regardless of whether they were accepted) was 158 for students who applied to more than one school.
} 
Thus, it is possible that the restricted variability used to identify the effect of school selectivity within matched groups of students does not influence earnings, whereas an experiment that moved students from a school with a 1,000 average SAT score to one with a 1,300 average would have a substantial effect on students' earnings. Although the latter experiment is relevant for larger considerations of education policy (such as affirmative action), specific instances of students who considered attending such a wide range of schools are rare. For parents and students, however, the relevant comparison is among the set of schools that admitted the student.

Our second model that adjusts for selection, the "self-revelation" model, is shown in column 3 of Tables $5 \mathrm{a}$ and $5 \mathrm{~b}$. This model includes the average SAT score of the schools to which students applied, and dummy variables indicating the number of schools to which students applied. The effect of school-average SAT score is qualitatively similar in the self-revelation and matched applicant models. In the self-revelation model for both of the samples, the effect of school-average SAT in column 3 is close to zero, and more precisely estimated than in the matched applicant model. Results of the self-revelation models are similar to those of the matched applicant models because students who apply to schools with the same mean SAT tend to apply to a fairly narrow range of schools around that mean. The average SAT score of the schools students applied to accounts for 62 percent of the variability in the SAT score of the schools students attended.

Table 6 presents parameter estimates from models that are similar to the self-revelation model, but use alternative selection controls in place of the average SAT score of the schools to which the student applied. For example, the third row reports estimates from a model that controls for the average SAT score of the schools at which the student was accepted. The results of this model are similar to those in the self-revelation model in row 2 , in that the effect on earnings of the 
average SAT score of the school that the student attended is indistinguishable from zero. We also obtain similar results when we control for the highest school-average SAT score among the colleges that accepted the student (row 4) or the highest school-average SAT score among the colleges to which the student applied (row 5). Moreover, we consistently find that the average SAT score of the schools the student applied to, but either was rejected by or chose not to attend, has a large effect on earnings. For example, results from the model in row 7 show that a 100 point increase in the highest school-average SAT score among the colleges at which the student was rejected is associated with an 8 percent increase in earnings. These results raise doubt about a causal interpretation of the effect of attending a school with a higher average SAT score in regressions that do not control for selection.

\section{A. Results for National Longitudinal Survey of the High School Class of 1972}

To explore the robustness of our results in a nationally representative data set, we analyzed data from the National Longitudinal Study of the High School Class of 1972 (NLS-72). We restrict the NLS-72 sample to those students who started at a four-year college or university in October of 1972, and we use 1985 annual earnings data from the fifth follow-up survey. In 1985 the NLS-72 respondents were about six years younger than the C\&B respondents were in 1995 (typically 31 versus 37). In the first follow-up survey, the NLS-72 asked students questions about other schools to which they may have applied in a fashion similar to the C\&B survey. ${ }^{22}$ The NLS-72 also

\footnotetext{
${ }^{22}$ Specifically, respondents were asked, "When you first applied, what was the name and address of the FIRST school or college of your choice? Were you accepted for admission at that school?" These questions were repeated for the respondents' second and third choice schools. We matched the responses to these questions to the HERI file to determine the average SAT score in 1973 of the schools that students applied to.
} 
contains detailed information about students' academic and family backgrounds, allowing us to construct most of the same variables used in Table 5. ${ }^{23}$ The NLS-72 survey did not, however, collect information on respondents' full-year work status in 1985 . We include in the sample all NLS-72 respondents (regardless of how much they worked) whose annual earnings exceeded $\$ 5,000$.

The means and standard deviations for the NLS-72 sample, as well as regression estimates, are reported in Table 7. Because the NLS-72 sample is relatively small (2,127 workers), we could not estimate the matched applicant model; however, we were able to estimate the basic regression model and self-revelation model for a pooled sample of men and women. The basic model without application controls, in column 2, indicates that a 100 point increase in the school-average SAT score is associated with approximately 5.1 percent higher annual earnings. However, the selfrevelation model reported in column 3 suggests that the effect of school-average SAT score is close to zero, although the standard error of .023 makes it difficult to draw a precise inference. The school SAT score estimates based on the comparable C\&B sample are strikingly similar: the coefficient (standard error) on school-average SAT score was $.055(.019)$ in the basic model and $-.022(.017)$ in the self-revelation model using the C\&B sample and imposing similar sample restrictions (in 1995 dollars). These results suggest that our findings in Tables $5 \mathrm{a}$ and $5 \mathrm{~b}$ are not unique to the schools covered by the C\&B survey.

\footnotetext{
${ }^{23}$ We have parental income data for most of the NLS-72 sample, allowing us to control for actual, rather than predicted, parental income. We do not include a dummy variable for athletes because NLS-72 does not identify varsity letter winners.
} 


\section{B. Interactions Between School-Average SAT and Student Characteristics}

Table 8 reports another set of estimates of the three models using the C\&B data set (basic, matched applicant, and self-revelation model) augmented to include an interaction between schoolaverage SAT and predicted log parental income. For the pooled sample of men and women, in all the models we estimated the coefficient on the interaction between parental income and schoolaverage SAT is negative, indicating a higher payoff to attending a more selective college for children from lower income households. The interaction term is statistically significant and generally has a sizable magnitude. For example, based on the self-revelation model in column 3 of Table 8, the gain from attending a college with a 200 point higher average SAT score for a family whose predicted log income is two standard deviations below the mean is 7 percent, versus virtually nil for a family with mean income.

In results not reported here, we also experimented with adding a variable to each model in Table 5a that interacted the students' own SAT score and the average SAT score of the school they attended. These estimates uniformly yielded significant negative effects on the own SAT-school SAT interaction term. Moreover, if we further allow for an asymmetric effect of the own SATschool SAT interaction for students whose SAT scores exceeded the school average (i.e., by also including the product of a dummy variable indicating students whose SAT score exceeded their school average and the interaction between school and own SAT), we continue to find negative effects of the interactions between own SAT and school SAT. Thus, there is no evidence in these data that students who score relatively low on the SAT exam do worse in the labor market by attending schools with a relatively high average SAT. 


\section{The Effect of Other College Characteristics on Earnings}

Although the average SAT score of the school a student attends does not have a robust effect on earnings once selection on unobservables is taken into account, we do find that the school a student attends is systematically related to his or her subsequent earnings. In particular, if we include 30 unrestricted dummy variables indicating school of attendance instead of the average SAT score in each of the models in Tables 5a and 5b, we reject the null hypothesis that schools are unrelated to earnings at the .01 level. Thus, something about schools appears to influence earnings. A possible reason for the insignificance of school-average SAT in the selection-adjusted models is that the average SAT score is a crude measure of the quality of one's peer group. Since, to some extent, all schools enroll a heterogeneous group of students, it might be possible for students to seek out the type of peer group they desire if they had attended any of the schools that admitted them. An able student who attends a lower tier school can find able students to study with, and, alas, a weak student who attends an elite school can find many other weak students to not study with. Our within-group models may place too much emphasis on an imperfect measure of school selectivity. Therefore, we next examine the effect of other college characteristics on students' subsequent earnings. First, we explore the effect on earnings of the dispersion in SAT scores within a school. Then we examine the return to the schools' average tuition costs (net of financial aid) and to their expenditures per student.

For each school in the C\&B data set, we calculated the standard deviation of SAT scores among freshmen in 1976. The standard deviation of within-school SAT scores ranged from 118 to 170 across schools, and the average standard deviation was 150 points. Across these colleges, the correlation between the average SAT score and standard deviation of scores is -.39 , which is 
consistent with less selective schools imposing a lower admissions threshold and attracting a more diverse student body in terms of achievement levels. We estimated a series of regressions in which we included the school-average SAT score, cross-sectional standard deviation of scores, and interaction between these two variables, in addition to the other variables in Table 5. The pattern of results was similar for the three models we estimated. The estimated coefficients and standard errors from the self-revelation model for the pooled sample of men and women are reported below (4) $\ln \mathrm{W}=.77 \mathrm{SAT}+6.10 \mathrm{SD}+-.53 \mathrm{SAT} * \mathrm{SD}+$ other variables (.44) (3.49) (.30)

where SAT is the school-average SAT (divided by 100), SD is the school standard deviation of SAT scores (divided by 100 ) and $\mathrm{SAT}^{*} \mathrm{SD}$ is the product of these two variables. Interestingly, each of the variables is on the margin of being individually statistically significant. The mean and dispersion of SAT scores among students in a college have a complex relationship with student earnings. A higher school-average SAT score is negatively associated with earnings for a college with dispersion in SAT scores greater than or equal to the average standard deviation of scores for this sample of 30 colleges. For the top two-thirds of the schools in our sample in terms of average SAT scores, greater dispersion in SAT scores is negatively associated with earnings. ${ }^{24}$

Table 9 presents models in which the logarithm of college tuition costs net of average student aid is the school quality indicator. ${ }^{25}$ For the pooled sample of men and women, these models indicate that students who attend higher tuition schools earn more after entering the labor

\footnotetext{
${ }^{24}$ This result is consistent with Hoxby and Terry (1998), although they do not present results controlling for selection on unobserved student characteristics.

${ }^{25} \mathrm{Net}$ tuition for 1970 and 1980 was calculated by subtracting the average aid awarded to undergraduates from the sticker price tuition, as reported in the $11^{\text {th }}$ and $12^{\text {th }}$ editions of American Universities and Colleges. Then the 1976 net tuition was interpolated from the 1970 and 1980 net tuition, assuming an exponential rate of growth.
} 
market. The magnitude of the coefficient on tuition falls in the models that adjust for school selection, but remains sizable. For example, the coefficient of .050 in column 5 implies an internal real rate of return of approximately 16 percent for a person who begins work after attending college for four years, then earns mean 1995 income throughout his career and retires 44 years later. ${ }^{26}$ The coefficient in column 3 implies an internal real rate of return of 18 percent. Notice also that the coefficient on the interaction term for parental income and tuition (shown in columns 2,4 , and 6 ) is negative, indicating that there is a higher payoff to attending a more expensive school for children from low-income families. Although the implied internal rates of return to investing in a more expensive college in Table 9 are extremely high, one should recognize that the cost of education has roughly doubled in real terms since the late 1970s, and the payoff to education increased in general since the late 1970s. The implicit internal real rate of return for the estimate in column 5 of Table 9 falls to 9 percent if tuition costs are doubled. Indeed, the supernormal return to investing in hightuition education in the 1970s may explain why it was possible for colleges to raise tuition so much in the 1980s and 1990s.

College tuition may have a significant effect on subsequent earnings because schools with higher tuition may provide their students with more, or higher quality, resources. We next summarize estimates of the effect of expenditures per student on subsequent earnings. Interestingly, the correlation between tuition and total expenditures per student in our sample of schools is less than .30 , so differences in tuition probably result from factors in addition to spending per student, such as the value of the school's endowment and public support. One should also recognize

\footnotetext{
${ }^{26}$ This rate of return would fall to 14 percent if we assumed that the person spent 1.5 years in graduate school (the average time spent in graduate school for the $C \& B$ sample) immediately after college.
} 
limitations of our measures of expenditures per students: (1) undergraduate and graduate student expenditures are combined; (2) there are inherent difficulties classifying instructional and noninstructional spending; and (3) expenditures are lumpy over time.

To directly explore the effect of school spending, we included either the log of total expenditures per student (undergraduate and graduate), or the log of instructional expenditures per student, in place of tuition in the earnings equation. ${ }^{27}$ Both measures of expenditures per pupil had a statistically significant and large impact on earnings in the basic model for the pooled sample of men and women. When we estimated the matched applicant model and the self-revelation model, the effect of expenditures per pupil was smaller, and less precisely estimated. Although the effect of expenditures per pupil was statistically insignificant, the coefficient was positive in all but one of the models, and implied substantial internal rates of return to school spending. ${ }^{28}$ These results provide mixed evidence on the effect of expenditures per student on students' subsequent income, perhaps because spending per student is poorly measured.

\section{$\underline{\text { D. Estimates for Black Students }}$}

Because of interest in the effect of affirmative action in admissions by more selective schools, we have estimated all the preceding models separately for black students using the C\&B data set. Unfortunately, the sample of black students who enrolled in these schools in 1976 is relatively small -- only 839 full-time workers. Consequently, our results are imprecise.

\footnotetext{
${ }^{27}$ We use 1976 expenditure data from the Integrated Postsecondary Education Data System (IPEDS) Survey.

${ }^{28}$ The coefficient (and standard error) on log instructional expenditures per student if this variable was included instead of tuition in column 1,3 and 5 of Table 9 were: $.096(.047) ; .073(.082)$; and $.036(.045)$. The corresponding coefficients for log total expenditures per student were: $.110(.066) ;-.009(.088)$; and $.041(.068)$.
} 
Nonetheless, there is no evidence that the relationship between school selectivity and subsequent earnings is different for black students. For example, when we estimate the model in column 1 of Table 5a for black students, the coefficient (and standard error) on school-average SAT is .060 (.025). The coefficient falls to $.024(.030)$ if the self-revelation model in column 3 is estimated. Similar to all students, black students who attended higher tuition schools had higher earnings when they joined the labor market, and the magnitudes on the coefficients were comparable to the estimates for the full sample. In general, these data suggest that black students benefit from attending more selective colleges just as much as other students, but we cannot draw a strong inference because of the small number of black students in our sample in 1976.

\section{Academic Outcomes}

Finally, we examined the relationship between school selectivity and three academic outcomes: the students' college grade point average (GPA), probability of graduating from the college they first attended, and probability of obtaining a post-college degree. Because of differences in grading schemes and generosity across schools, we measure grades within colleges, by the students' GPA percentile rank in their class. For each outcome, we estimated a linear probability model for each of our three classes of models using the pooled sample of men and women. Results are reported in Table 10.

In all three classes of models, students who attended a college with a higher average SAT score tended to have a lower rank in the class, other things equal. ${ }^{29}$ For example, according to the

\footnotetext{
${ }^{29}$ Bowen and Bok (1998) report a similar result.
} 
basic model, students who attended a college with a 100 point higher average SAT score tended to graduate 5.6 percentile ranks lower in their class. The corresponding deficit was 7.8 percentile ranks in the matched applicant model and 6.4 percentile ranks in the self-revelation model. The improvement in class rank for students who choose to attend a less selective college may help explain why those students do not appear to incur lower earnings; employers (and graduate schools) may value their higher class rank by enough to offset any other effect of attending a less selective college on earnings. If we add class rank to the wage regressions in Table 5a, we find that students who graduate 7 percentile ranks higher in their class earn about 3.2 percent higher earnings, which may largely offset any advantage of attending an elite college on earnings.

Lastly, Table 10 provides mixed evidence for the effect of school-average SAT on graduation rates and advanced degrees. The effect of school-average SAT score on graduation rates is indistinguishable from zero in all three models. On the other hand, school-average SAT score has a positive and significant effect on the probability of obtaining an advanced degree in both the basic model and the self-revelation model; however, the effect is statistically insignificant in the matched applicant model.

\section{Conclusion}

The colleges that students attend are affected by selection on the part of the schools that students apply to, and by selection on the part of the students and their families from the menu of feasible options. A major concern with past estimates of the payoff to attending an elite college is that more selective schools tend to accept students with higher earnings capacity. This paper adjusts for selection on the part of schools by comparing earnings and other outcomes among 
students who applied to, and were accepted and rejected by, a comparable set of institutions. Although our selection correction has many desirable features, a complete analysis of school selection also would model students' choice of colleges. Nonetheless, since college admission decisions are made by professional administrators who have much more information at their disposal than researchers who later analyze student outcomes, we suspect that our selection correction addresses a major cause of bias in past wage equations.

After we adjust for students' unobserved characteristics, our findings cast doubt on the view that school selectivity, as measured by the average SAT score of the freshmen who attend a college, is an important determinant of students' subsequent incomes. Students who attended more selective colleges do not earn more than other students who were accepted and rejected by comparable schools but attended less selective colleges. Additional evidence of omitted variable bias due to the college application and admissions process comes from the fact that the average SAT score of schools that a student applied to but was rejected from has a stronger effect on the student's subsequent earnings than the average SAT score of the school the student actually attended. These results are consistent with the conclusion of Hunt's (1963; p. 56) seminal research:

The C student from Princeton earns more than the A student from Podunk not mainly because he has the prestige of a Princeton degree, but merely because he is abler. The golden touch is possessed not by the Ivy League College, but by its students.

Even after adjusting for selection, however, we do find that the school a student attends affects his or her subsequent income. The characteristics of schools that influence students' subsequent income appear to be better captured by average tuition costs than by the school's average SAT score. Indeed, we find that students who attend colleges with higher average tuition costs tend to earn higher income years later. The internal real rate of return on college tuition for 
students who attended college in the late 1970s was quite high, in the neighborhood of 16 to 18 percent. But college tuition costs have risen considerably since the 1970s, driving the internal rate of return to a more normal level.

Finally, we find that the returns to school characteristics such as average SAT score or tuition are greatest for students from more disadvantaged backgrounds. School admissions and financial aid policies that have as a goal attracting qualified students from more disadvantaged family backgrounds may raise national income, as these students appear to benefit most from attending a more elite college. Ellwood and Kane's (1998) recent finding that college enrollment hardly increased for children from low-income families in the 1980s is troubling in this regard. 


\section{References}

American Council on Education, American Universities and Colleges, $12^{\text {th }}$ edition (Hawthorn, New York: Walter de Gruyter, 1983).

Barron's, 1982, Barron's Profiles of American Colleges (Woodbury, NY: Barron's Educational Series, 12 th edition).

Barnow, Burt S., Glen G. Cain and Arthur Goldberger, "Selection on Observables," Evaluation Studies Review Annual, 5:43-59, 1981.

Behrman, Jere R., Jill Constantine, Lori Kletzer, Michael McPherson, and Morton O. Schapiro, "The Impact of College Quality on Wages: Are There Differences Among Demographic Groups?" Working Paper No. DP-38, William College, 1996.

Behrman, Jere R., Mark R. Rosenzweig and Paul Taubman, "College Choice and Wages: Estimates Using Data on Female Twins," Review of Economics and Statistics, 78 (4), 1996, pp. 672-85.

Bowen, William G., and Derek Bok, The Shape of the River: Long-Term Consequences of Considering Race in College and University Admissions (Princeton, NJ: Princeton University Press, 1998).

Braun, Henry and Ted Szatrowski, "The Scale-Linkage Algorithm: Construction of a Universal Criterion Scale for Families of Institutions," Journal of Educational Statistics 9, 1984, pp. 311-330.

Breneman, David W. Liberal Arts Colleges: Thriving, Surviving or Endangered (Washington, D.C.: The Brookings Institution, 1994).

Brewer, Dominic and Ronald Ehrenberg, "Does it Pay to Attend an Elite Private College? Evidence from the Senior High School Class of 1980" in Research in Labor Economics, vol. 15, pp. 239-71.

Brewer, Dominic, Eric Eide and Ronald Ehrenberg, "Does it Pay to Attend an Elite College? Cross Cohort Evidence on the Effects of College Type on Earnings," Journal of Human Resources 34 (1), Winter 1999, pp. 104-23.

Daniel, Kermit, Dan Black, and Jeffrey Smith, "College Quality and the Wages of Young Men," Research Report No. 9707, Department of Economics, University of Western Ontario, 1997.

Ellwood, David and Thomas Kane, "Who is Getting a College Education: Family Background and the Growing Gaps in Enrollment," Mimeo., Kennedy School of Government, September 1998.

Furniss, Todd W., ed. American Universities and Colleges, $11^{\text {th }}$ edition (Washington D.C.: American Council on Education, 1973). 
Griliches, Zvi, "Sibling Models and Data in Economics: Beginnings of a Survey," Journal of Political Economy, 87 (5), 1979, pp. S37-S64.

Grover, Ronald, "How Steven Spielberg Sustains His Creative Empire," Business Week, July 13, 1998, p. 96.

Heckman, James, "Sample Selection Bias as a Specification Error," Econometrica 47 (1), 1979, pp. $153-61$.

Hoxby, Caroline, and Bridget Terry, "Explaining Rising Income and Wage Inequality Among the College-Educated,” Mimeo., Harvard University, April, 1999.

Hunt, Shane, "Income Determinants for College Graduates and the Return to Educational Investment." Unpublished Ph.D. Disseration, Yale University, 1963.

Kane, Thomas, "Racial and Ethnic Preferences in College Admission," in The Black-White Test Score Gap, edited by C. Jencks and M. Phillips, Washington, D.C.: Brookings Institution, 1998.

National Association for College Admission Counseling, "Survey Examines Trends," the NACAC Bulletin, November, 1998, p. 1.

Solmon, Lewis, "The Definition of College Quality," in Does College Matter: Some Evidence on the Impacts of Higher Education, edited by Lewis Solmon and Paul Taubman (New York: Academic Press, 1973).

Solmon, Lewis, and Paul Wachtel, "The Effects on Income of Type of College Attended," Sociology of Education 48, 1975, pp. 75-90.

U.S. Department of Education, National Center for Education Statistics, Digest of Education Statistics 1997, NCES 98-015, Washington, D.C., 1997.

Van der Klaauw, Wilbert, "A Regression-Discontinuity Evaluation of the Effect of Financial Aid Offers on College Enrollment," Mimeo., Department of Economics, NYU, October 1997.

Wales, Terence, "The Effect of College Quality on Earnings: Results from the NBER-Thorndike Data," Journal of Human Resources 8, 1973, pp. 306-17.

Winston, Gordon, and Ivan Yen, "Costs, Prices, Subsidies, and Aid in U.S. Higher Education," Working Paper DP-32, Williams College, July, 1995.

Wise, David, "Academic Achievement and Job Performance," American Economic Review 65, 1975, pp. 350-66. 
</ref_section> 


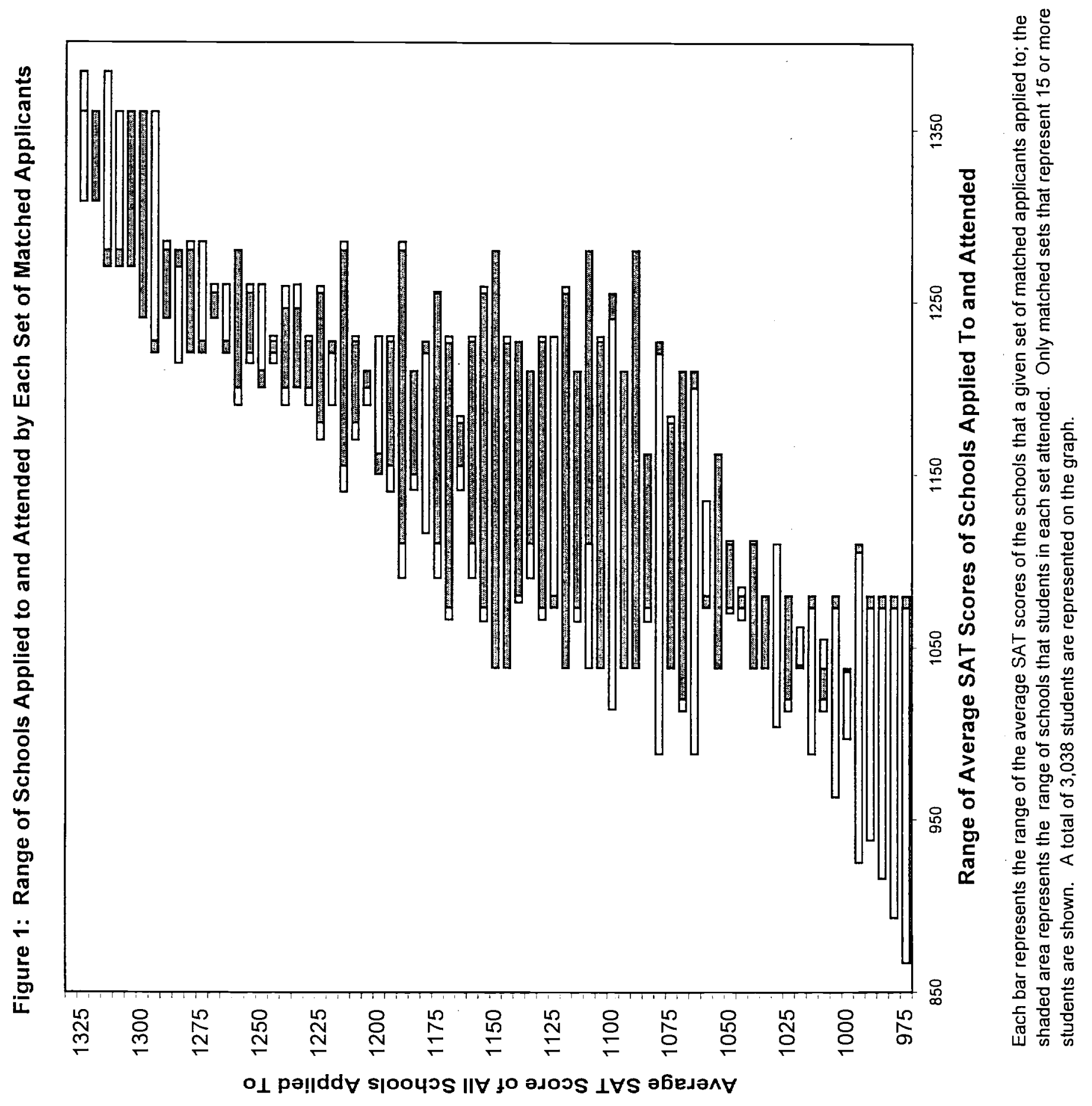


Table 1

Average Regression Statistics from Simulating Selection Correction Model 100 Times

Panel A: All Students Apply to Four Schools; Random Matriculation

\begin{tabular}{|c|c|c|c|c|}
\hline \multirow[b]{3}{*}{ Variable } & \multicolumn{4}{|c|}{ Parameter Estimates } \\
\hline & & & & \multirow[b]{2}{*}{ (4) } \\
\hline & (1) & $(2)$ & (3) & \\
\hline \multirow[t]{2}{*}{ Intercept } & 0.50 & 0.50 & 0.59 & -0.08 \\
\hline & $(0.02)$ & $(0.02)$ & $(0.58)$ & $(0.04)$ \\
\hline \multirow[t]{2}{*}{ School Average $S A T_{j}^{*}$} & 0.01 & 0.58 & 0.01 & 0.01 \\
\hline & $(0.05)$ & $(0.05)$ & $(0.06)$ & $(0.06)$ \\
\hline \multirow[t]{2}{*}{$X_{1}$ (e.g., own SAT) } & 0.50 & 0.42 & 0.26 & 0.26 \\
\hline & $(0.02)$ & $(0.02)$ & $(0.02)$ & $(0.02)$ \\
\hline \multirow[t]{2}{*}{$\mathrm{X}_{2}$ (e.g., unobserved ability) } & 0.50 & -- & - & -- \\
\hline & $(0.02)$ & & & \\
\hline $\begin{array}{l}15 \text { dummies for College Acceptance } \\
\text { and Rejection Configurations }{ }^{1}\end{array}$ & No & No & Yes & No \\
\hline $\begin{array}{l}3 \text { dummies indicating } \\
\text { College Acceptance }\end{array}$ & No & No & No & Yes \\
\hline $\mathrm{R}^{2}$ & 0.33 & 0.19 & 0.25 & 0.24 \\
\hline
\end{tabular}

-Continued- 
Panel B: Bottom 40 Percent of Students Apply to Two Schools; Matriculation at Best School Related to X1 $+X 2>0$ and Chance

\begin{tabular}{|c|c|c|c|c|}
\hline \multirow[b]{3}{*}{ Variable } & \multicolumn{4}{|c|}{ Parameter Estimates } \\
\hline & \multicolumn{3}{|c|}{ Model } & \multirow[b]{2}{*}{ (4) } \\
\hline & (1) & (2) & (3) & \\
\hline \multirow[t]{2}{*}{ Intercept } & 0.50 & 0.50 & 0.43 & 0.17 \\
\hline & $(0.02)$ & $(0.02)$ & $(0.58)$ & $(0.06)$ \\
\hline \multirow[t]{2}{*}{ School Average SAT ${ }_{j}^{*}$} & 0.00 & 0.75 & 0.32 & 0.40 \\
\hline & $(0.05)$ & $(0.04)$ & $(0.08)$ & $(0.08)$ \\
\hline \multirow[t]{2}{*}{$X_{1}$ (e.g., own SAT) } & 0.50 & 0.25 & 0.19 & 0.23 \\
\hline & $(0.02)$ & $(0.02)$ & $(0.02)$ & $(0.02)$ \\
\hline \multirow[t]{2}{*}{$X_{2}$ (e.g., unobserved ability) } & 0.50 & -- & -- & -- \\
\hline & $(0.02)$ & & & \\
\hline $\begin{array}{l}17 \text { dummies for College Acceptance } \\
\text { and Rejection Configurations }{ }^{1}\end{array}$ & No & No & Yes & No \\
\hline $\begin{array}{l}3 \text { dummies indicating } \\
\text { College Acceptance }\end{array}$ & No & No & No & Yes \\
\hline $\mathrm{R}^{2}$ & 0.33 & 0.25 & 0.27 & 0.26 \\
\hline
\end{tabular}

Notes:

1. Actual number of dummies is usually fewer because of empty cells.

2. Each simulated sample had 4,000 observations. See text for further details.

The standard deviation of each estimated coefficient is in parentheses. 
Table 2

Illustration of How Matched Applicant Groups Were Constructed

\begin{tabular}{|c|c|c|c|c|c|c|c|c|c|}
\hline \multirow[b]{3}{*}{ Student } & \multirow[b]{3}{*}{$\begin{array}{l}\text { Matched } \\
\text { Applicant } \\
\text { Group } \\
\end{array}$} & \multicolumn{8}{|c|}{ Student Applications to College } \\
\hline & & \multicolumn{2}{|c|}{ Application 1} & \multicolumn{2}{|c|}{ Application 2} & \multicolumn{2}{|c|}{ Application 3} & \multicolumn{2}{|c|}{ Application 4} \\
\hline & & $\begin{array}{c}\text { School } \\
\text { Average } \\
\text { SAT }\end{array}$ & $\begin{array}{c}\text { School } \\
\text { Admissions } \\
\text { Decision }\end{array}$ & $\begin{array}{c}\text { School } \\
\text { Average } \\
\text { SAT }\end{array}$ & $\begin{array}{c}\text { School } \\
\text { Admissions } \\
\text { Decision }\end{array}$ & $\begin{array}{c}\text { School } \\
\text { Average } \\
\text { SAT }\end{array}$ & $\begin{array}{c}\text { School } \\
\text { Admissions } \\
\text { Decision } \\
\end{array}$ & $\begin{array}{c}\text { School } \\
\text { Average } \\
\text { SAT }\end{array}$ & $\begin{array}{c}\text { School } \\
\text { Admissions } \\
\text { Decision }\end{array}$ \\
\hline Student A & 1 & 1280 & Reject & 1226 & Accept* & 1215 & Accept & na & na \\
\hline Student B & 1 & 1280 & Reject & 1226 & Accept & 1215 & Accept ${ }^{\star}$ & na & na \\
\hline Student C & 2 & 1360 & Accept & 1310 & Reject & 1270 & Accept* & 1155 & Accept \\
\hline Student D & 2 & 1355 & Accept & 1316 & Reject & 1270 & Accept* & 1160 & Accept \\
\hline Student E & 2 & 1370 & Accept* & 1316 & Reject & 1260 & Accept & 1150 & Accept \\
\hline Student F & Excluded & 1180 & Accept* & na & na & na & na & na & na \\
\hline Student $G$ & Excluded & 1180 & Accept $t^{\star}$ & na & na & na & na & na & na \\
\hline Student $H$ & 3 & 1360 & Accept & 1308 & Accept ${ }^{*}$ & 1260 & Accept & 1160 & Accept \\
\hline Student I & 3 & 1370 & Accept $^{*}$ & 1311 & Accept & 1255 & Accept & 1155 & Accept \\
\hline Student J & 3 & 1350 & Accept & 1316 & Accept ${ }^{*}$ & 1265 & Accept & 1155 & Accept \\
\hline Student $K$ & 4 & 1245 & Reject & 1217 & Reject & 1180 & Accept* & na & na \\
\hline Student L & 4 & 1235 & Reject & 1209 & Reject & 1180 & Accept $^{\star}$ & na & na \\
\hline Student $M$ & 5 & 1140 & Accept & 1055 & Accept $^{*}$ & na & na & na & na \\
\hline Student N & 5 & 1145 & Accept $^{*}$ & 1060 & Accept & na & na & na & na \\
\hline Student $O$ & No Match & 1370 & Reject & 1038 & Accept ${ }^{*}$ & na & na & na & na \\
\hline
\end{tabular}

^Denotes school attended

na=did not report submitting application

Notes: The data shown on this table represent hypothetical students. Students $F$ and $G$ would be excluded from the matched applicant subsample because they only applied to one school (the school they attended). Student $O$ would be excluded because no other student applied to an equivalent set of institutions. 


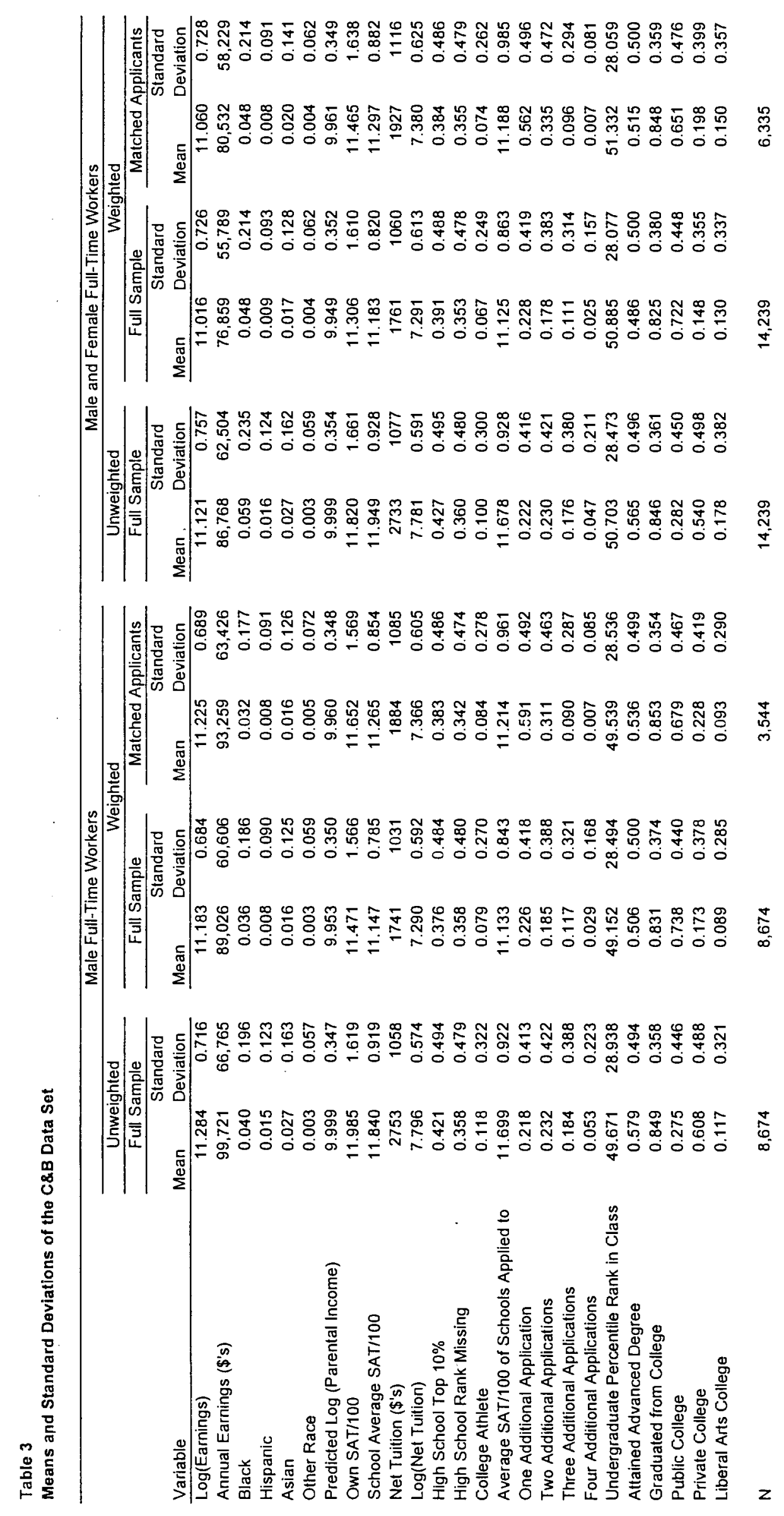


Table 4

Comparison of Estimates from C\&B to Estimates from National Samples

\begin{tabular}{|c|c|c|c|c|}
\hline \multirow[b]{4}{*}{ Variable Name } & \multicolumn{4}{|c|}{ Parameter Estimates } \\
\hline & \multicolumn{2}{|c|}{ Men and Women } & \multicolumn{2}{|c|}{ Men Only } \\
\hline & C\&B & $\begin{array}{c}\text { HSB } \\
\text { (Kane) }\end{array}$ & C\&B & $\begin{array}{c}\text { NLSY } \\
\text { (Daniel, et al.) }\end{array}$ \\
\hline & 1 & 2 & 3 & 4 \\
\hline School-Average SAT Score/100 & $\begin{array}{r}0.069 \\
(0.018)\end{array}$ & $\begin{array}{r}0.056 \\
(0.010)\end{array}$ & $\begin{array}{r}0.087 \\
(0.021)\end{array}$ & $\begin{array}{r}0.061 \\
(0.013)\end{array}$ \\
\hline Own SAT Score/100 & $\begin{array}{r}0.026 \\
(0.006)\end{array}$ & * & $\begin{array}{r}0.036 \\
(0.008)\end{array}$ & ** \\
\hline Female & $\begin{array}{r}-0.625 \\
(0.017)\end{array}$ & * & & \\
\hline Black or Hispanic & $\begin{array}{r}0.076 \\
(0.017)\end{array}$ & $\begin{array}{r}-0.006 \\
(0.025)\end{array}$ & & \\
\hline Years of Father's Education & $\begin{array}{r}0.004 \\
(0.003)\end{array}$ & * & $\cdot$ & \\
\hline Years of Mother's Education & $\begin{array}{r}-0.002 \\
(0.004)\end{array}$ & * & & \\
\hline Parental Income (10K) & $\begin{array}{r}0.054 \\
(0.008)\end{array}$ & * & & \\
\hline Parental Income Missing & $\begin{array}{r}0.150 \\
(0.016)\end{array}$ & * & & \\
\hline High School Top Ten & $\begin{array}{r}0.091 \\
(0.012)\end{array}$ & * & & \\
\hline High School Rank Missing & $\begin{array}{r}-0.002 \\
(0.044)\end{array}$ & & & \\
\hline Any Post-Secondary Schooling & & & & ** \\
\hline $\mathbf{N}$ & 17,213 & 3,686 & 9,106 & 3,100 \\
\hline
\end{tabular}

*This regression includes controls for parental education, family income, gender, student SAT, and high school grade point average; however, the coefficients are not reported in Kane (1998).

**This regression includes controls for student ability (age-adjusted ASVAB scores), and a dummy indicating whether the respondent had any post-secondary schooling; however, the coefficients are not reported in Daniel, et al. (1997).

Notes: All equations also include constant terms. Standard errors are in parentheses.

The C\&B model in column 1 includes all survey respondents, except those who earned less than $\$ 1,000$. The HSB regression in column 2 excludes those who earned less than $\$ 1,000$ or more than $\$ 100,000$ in 1991 . The C\&B model in column 3 and the NLSY model in column 4 include all male workers, regardless of whether they worked full-time.

C\&B estimates are weighted using sample weights, and the reported standard errors are robust to correlated errors among students who attended the same institution. 
Table 5a

Log Earnings Regressions for C\&B Pooled Sample of Male and Female Full-Time Workers

\begin{tabular}{|c|c|c|c|}
\hline \multirow[b]{3}{*}{ Variable } & \multicolumn{3}{|c|}{ Parameter Estimates } \\
\hline & $\begin{array}{l}\text { Basic Model: } \\
\text { No Selection } \\
\text { Controls } \\
\end{array}$ & $\begin{array}{l}\text { Matched } \\
\text { Applicant } \\
\text { Model }^{*} \\
\end{array}$ & $\begin{array}{c}\text { Self- } \\
\text { Revelation } \\
\text { Model } \\
\end{array}$ \\
\hline & 1 & 2 & 3 \\
\hline School-Average SAT Score/100 & $\begin{array}{r}0.060 \\
(0.016)\end{array}$ & $\begin{array}{r}-0.025 \\
(0.028)\end{array}$ & $\begin{array}{r}-0.009 \\
(0.019)\end{array}$ \\
\hline Predicted Log(Parental Income) & $\begin{array}{r}0.201 \\
(0.020)\end{array}$ & $\begin{array}{r}0.194 \\
(0.026)\end{array}$ & $\begin{array}{r}0.180 \\
(0.021)\end{array}$ \\
\hline OWn SAT Score/100 & $\begin{array}{r}0.028 \\
(0.006)\end{array}$ & $\begin{array}{c}-0.004 \\
(0.006)\end{array}$ & $\begin{array}{r}0.020 \\
(0.005)\end{array}$ \\
\hline Female & $\begin{array}{r}-0.396 \\
(0.015)\end{array}$ & $\begin{array}{r}-0.417 \\
(0.025)\end{array}$ & $\begin{array}{l}-0.389 \\
(0.014)\end{array}$ \\
\hline Black & $\begin{array}{r}0.020 \\
(0.029)\end{array}$ & $\begin{array}{r}-0.023 \\
(0.053)\end{array}$ & $\begin{array}{r}0.009 \\
(0.030)\end{array}$ \\
\hline Hispanic & $\begin{array}{r}0.011 \\
(0.041)\end{array}$ & $\begin{array}{r}-0.106 \\
(0.118)\end{array}$ & $\begin{array}{r}0.006 \\
(0.045)\end{array}$ \\
\hline Asian & $\begin{array}{r}0.212 \\
(0.035)\end{array}$ & $\begin{array}{r}0.280 \\
(0.070)\end{array}$ & $\begin{array}{r}0.193 \\
(0.036)\end{array}$ \\
\hline Other/Missing Race & $\begin{array}{r}-0.198 \\
(0.148)\end{array}$ & $\begin{array}{r}0.202 \\
(0.211)\end{array}$ & $\begin{array}{r}-0.204 \\
(0.145)\end{array}$ \\
\hline High School Top Ten Percent & $\begin{array}{r}0.055 \\
(0.023)\end{array}$ & $\begin{array}{r}0.093 \\
(0.022)\end{array}$ & $\begin{array}{r}0.057 \\
(0.024)\end{array}$ \\
\hline High School Rank Missing & $\begin{array}{r}0.000 \\
(0.038)\end{array}$ & $\begin{array}{r}0.036 \\
(0.060)\end{array}$ & $\begin{array}{r}-0.010 \\
(0.035)\end{array}$ \\
\hline Athlete & $\begin{array}{r}0.111 \\
(0.025)\end{array}$ & $\begin{array}{r}0.138 \\
(0.048)\end{array}$ & $\begin{array}{r}0.103 \\
(0.022)\end{array}$ \\
\hline Average SAT Score/ 100 of Schools Applied To & & & $\begin{array}{r}0.079 \\
(0.016)\end{array}$ \\
\hline One Additional Application & & & $\begin{array}{r}0.055 \\
(0.009)\end{array}$ \\
\hline Two Additional Applications & & & $\begin{array}{r}0.066 \\
(0.026)\end{array}$ \\
\hline Three Additional Applications & & & $\begin{array}{r}0.096 \\
(0.039)\end{array}$ \\
\hline Four Additional Applications & & & $\begin{array}{r}0.093 \\
(0.042)\end{array}$ \\
\hline Adjusted R Squared & 0.110 & 0.144 & 0.115 \\
\hline $\mathrm{N}$ & 14,239 & 6,335 & 14,239 \\
\hline
\end{tabular}

Notes: Each equation also includes a constant term. Standard errors are in parentheses, and are are robust to correlated errors among students who attended the same institution. Equations are estimated by WLS.

*Applicants are matched by the average SAT score (within 25 point intervals) of each school at which they were accepted or rejected. This model includes 1,232 dummy variables representing each set of matched applicants. 
Table 5b

Log Earnings Regression for Male Full-Time Workers, C\&B Sample

\begin{tabular}{|c|c|c|c|}
\hline \multirow[b]{3}{*}{ Variable } & \multicolumn{3}{|c|}{ Parameter Estimates } \\
\hline & $\begin{array}{c}\text { Basic Model: } \\
\text { No Selection } \\
\text { Controls } \\
\end{array}$ & $\begin{array}{l}\text { Matched } \\
\text { Applicant } \\
\text { Model }^{\star} \\
\end{array}$ & $\begin{array}{c}\text { Self- } \\
\text { Revelation } \\
\text { Model } \\
\end{array}$ \\
\hline & 1 & & 3 \\
\hline School-Average SAT Score/100 & $\begin{array}{r}0.071 \\
(0.020)\end{array}$ & $\begin{array}{r}-0.002 \\
(0.044)\end{array}$ & $\begin{array}{r}-0.004 \\
(0.025)\end{array}$ \\
\hline Predicted Log(Parental Income) & $\begin{array}{r}0.241 \\
(0.031)\end{array}$ & $\begin{array}{r}0.176 \\
(0.067)\end{array}$ & $\begin{array}{r}0.217 \\
(0.030)\end{array}$ \\
\hline Own SAT Score/100 & $\begin{array}{r}0.026 \\
(0.007)\end{array}$ & $\begin{array}{r}-0.010 \\
(0.020)\end{array}$ & $\begin{array}{r}0.016 \\
(0.006)\end{array}$ \\
\hline Black & $\begin{array}{r}-0.099 \\
(0.040)\end{array}$ & $\begin{array}{r}-0.183 \\
(0.087)\end{array}$ & $\begin{array}{r}-0.112 \\
(0.039)\end{array}$ \\
\hline Hispanic & $\begin{array}{r}-0.004 \\
(0.043)\end{array}$ & $\begin{array}{r}-0.170 \\
(0.157)\end{array}$ & $\begin{array}{r}-0.004 \\
(0.041)\end{array}$ \\
\hline Asian & $\begin{array}{r}0.126 \\
(0.059)\end{array}$ & $\begin{array}{r}0.239 \\
(0.085)\end{array}$ & $\begin{array}{r}0.105 \\
(0.060)\end{array}$ \\
\hline Other/Missing Race & $\begin{array}{r}-0.195 \\
(0.271)\end{array}$ & $\begin{array}{r}0.450 \\
(0.373)\end{array}$ & $\begin{array}{r}-0.208 \\
(0.267)\end{array}$ \\
\hline High School Top Ten Percent & $\begin{array}{r}0.016 \\
(0.021)\end{array}$ & $\begin{array}{r}0.077 \\
(0.035)\end{array}$ & $\begin{array}{r}0.020 \\
(0.023)\end{array}$ \\
\hline High School Rank Missing & $\begin{array}{r}-0.025 \\
(0.027)\end{array}$ & $\begin{array}{r}0.013 \\
(0.061)\end{array}$ & $\begin{array}{r}-0.035 \\
(0.024)\end{array}$ \\
\hline Athlete & $\begin{array}{r}0.107 \\
(0.027)\end{array}$ & $\begin{array}{r}0.111 \\
(0.037)\end{array}$ & $\begin{array}{r}0.094 \\
(0.024)\end{array}$ \\
\hline Average SAT Score/100 of Schools Applied To & & & $\begin{array}{r}0.088 \\
(0.023)\end{array}$ \\
\hline One Additional Application & & & $\begin{array}{r}0.061 \\
(0.015)\end{array}$ \\
\hline Two Additional Applications & & & $\begin{array}{r}0.043 \\
(0.019)\end{array}$ \\
\hline Three Additional Applications & & & $\begin{array}{r}0.119 \\
(0.030)\end{array}$ \\
\hline Four Additional Applications & & & $\begin{array}{r}0.060 \\
(0.034)\end{array}$ \\
\hline Adjusted R Squared & 0.043 & 0.094 & 0.051 \\
\hline $\mathrm{N}$ & 8,674 & 3,544 & 8,674 \\
\hline
\end{tabular}

Notes: Each equation also includes a constant term. Standard errors are in parentheses, and are are robust to correlated errors among students who attended the same institution.

Equations are estimated by WLS.

"Applicants are matched by the average SAT score (within 25 point intervals) of each school at which they were accepted or rejected. This model includes 770 dummy variables representing each set of matched applicants. 
Table 6

The Effect of School-Average SAT Score on Earnings in Models that Use Alternative Selection Controls, C\&B Pooled Sample of Male and Female Full-Time Workers

\begin{tabular}{|c|c|c|c|}
\hline \multirow[b]{2}{*}{$\begin{array}{c}\text { Type of Selection } \\
\text { Control }\end{array}$} & \multicolumn{2}{|c|}{ Parameter Estimates } & \multirow[b]{2}{*}{$N$} \\
\hline & $\begin{array}{c}\text { School-Average } \\
\text { SAT Score }\end{array}$ & $\begin{array}{c}\text { Selection } \\
\text { Control }\end{array}$ & \\
\hline (1) None (Basic Model) & $\begin{array}{c}0.060 \\
(0.016)\end{array}$ & - & 14,239 \\
\hline $\begin{array}{l}\text { (2) Average SAT Score/100 of Schools } \\
\text { Applied to (Self-Revelation Model) }\end{array}$ & $\begin{array}{l}-0.009 \\
(0.019)\end{array}$ & $\begin{array}{c}0.079 \\
(0.016)\end{array}$ & 14,239 \\
\hline $\begin{array}{l}\text { (3) Average SAT Score/100 } \\
\text { of Schools Accepted by }\end{array}$ & $\begin{array}{l}-0.008 \\
(0.022)\end{array}$ & $\begin{array}{c}0.073 \\
(0.021)\end{array}$ & 14,239 \\
\hline $\begin{array}{l}\text { (4) Highest SAT Score/100 of } \\
\text { Schools Accepted by }\end{array}$ & $\begin{array}{l}-0.014 \\
(0.023)\end{array}$ & $\begin{array}{r}0.081 \\
(0.024)\end{array}$ & 14,239 \\
\hline $\begin{array}{l}\text { (5) Highest SAT Score/100 of } \\
\text { All Schools Applied to }\end{array}$ & $\begin{array}{c}0.002 \\
(0.018)\end{array}$ & $\begin{array}{c}0.077 \\
(0.015)\end{array}$ & 14,239 \\
\hline $\begin{array}{l}\text { (6) Highest SAT Score/100 of Schools } \\
\text { Applied to but not Attended }\end{array}$ & $\begin{array}{c}0.029 \\
(0.015)\end{array}$ & $\begin{array}{l}0.047 \\
(0.006)\end{array}$ & 9,358 \\
\hline $\begin{array}{l}\text { (7) Average SAT Score/100 of Schools } \\
\text { Rejected by }\end{array}$ & $\begin{array}{c}0.039 \\
(0.014)\end{array}$ & $\begin{array}{c}0.081 \\
(0.014)\end{array}$ & 3,805 \\
\hline $\begin{array}{l}\text { (8) Highest SAT Score/100 of Schools } \\
\text { Accepted by but not Attended }\end{array}$ & $\begin{array}{c}0.025 \\
(0.015)\end{array}$ & $\begin{array}{c}0.043 \\
(0.010)\end{array}$ & 8,257 \\
\hline
\end{tabular}

Notes: Each model also includes the same control variables as the Self-Revelation Model shown in column 3 of Table $5 \mathrm{a}$. Standard errors are in parentheses and are robust to correlated errors among students who attended the same institution. Equations are estimated by WLS. The first data column presents the coefficient on the average SAT score at the school the student attended; the second data column presents the coefficient on the selection control described in the left margin of the table. 
Table 7

Means, Standard Deviations, and Log Earnings Regressions for NLS-72 Pooled Sample of Male and Female Workers

\begin{tabular}{|c|c|c|c|}
\hline \multirow[b]{3}{*}{ Variable Name } & \multirow{3}{*}{$\begin{array}{c}\begin{array}{c}\text { Variable Means } \\
\text { [Standard Deviation] }\end{array} \\
1\end{array}$} & \multicolumn{2}{|c|}{ Parameter Estimates } \\
\hline & & $\begin{array}{c}\text { Basic Model: } \\
\text { No Selection Controls } \\
\end{array}$ & $\begin{array}{c}\text { Self-Revelation } \\
\text { Model }\end{array}$ \\
\hline & & $\begin{array}{c}2 \\
\end{array}$ & 3 \\
\hline School-Average SAT Score/100 & $\begin{array}{r}9.943 \\
{[1.181]}\end{array}$ & $\begin{array}{r}0.051 \\
(0.010)\end{array}$ & $\begin{array}{r}0.013 \\
(0.023)\end{array}$ \\
\hline Log(Parental Income) & $\begin{array}{r}9.455 \\
{[0.615]}\end{array}$ & $\begin{array}{r}0.081 \\
(0.018)\end{array}$ & $\begin{array}{r}0.074 \\
(0.018)\end{array}$ \\
\hline OWn SAT Score/100 & $\begin{array}{r}9.755 \\
{[2.057]}\end{array}$ & $\begin{array}{r}0.022 \\
(0.006)\end{array}$ & $\begin{array}{r}0.020 \\
(0.006)\end{array}$ \\
\hline Female & $\begin{array}{r}0.398 \\
{[0.489]}\end{array}$ & $\begin{array}{l}-0.384 \\
(0.022)\end{array}$ & $\begin{array}{l}-0.384 \\
(0.022)\end{array}$ \\
\hline Black & $\begin{array}{r}0.060 \\
{[0.238]}\end{array}$ & $\begin{array}{r}0.065 \\
(0.047)\end{array}$ & $\begin{array}{r}0.053 \\
(0.047)\end{array}$ \\
\hline Hispanic & $\begin{array}{r}0.016 \\
{[0.124]}\end{array}$ & $\begin{array}{r}0.096 \\
(0.084)\end{array}$ & $\begin{array}{r}0.085 \\
(0.084)\end{array}$ \\
\hline Asian & $\begin{array}{r}0.010 \\
{[0.099]}\end{array}$ & $\begin{array}{r}-0.175 \\
(0.103)\end{array}$ & $\begin{array}{l}-0.167 \\
(0.103)\end{array}$ \\
\hline Other/Missing Race & $\begin{array}{r}0.023 \\
{[0.151]}\end{array}$ & $\begin{array}{r}-0.525 \\
(0.069)\end{array}$ & $\begin{array}{l}-0.503 \\
(0.069)\end{array}$ \\
\hline High School Top Ten Percent & $\begin{array}{r}0.201 \\
{[0.401]}\end{array}$ & $\begin{array}{r}0.055 \\
(0.029)\end{array}$ & $\begin{array}{r}0.063 \\
(0.030)\end{array}$ \\
\hline High School Rank Missing & $\begin{array}{r}0.193 \\
{[0.394]}\end{array}$ & $\begin{array}{r}0.039 \\
(0.027)\end{array}$ & $\begin{array}{r}0.040 \\
(0.027)\end{array}$ \\
\hline Average SAT Score 1100 of Schools Applied To & $\begin{array}{r}9.996 \\
{[1.114]}\end{array}$ & & $\begin{array}{r}0.034 \\
(0.025)\end{array}$ \\
\hline One Additional Application & $\begin{array}{r}0.246 \\
{[0.431]}\end{array}$ & & $\begin{array}{r}0.026 \\
(0.025)\end{array}$ \\
\hline Two Additional Applications & $\begin{array}{r}0.202 \\
{[0.402]}\end{array}$ & & $\begin{array}{r}0.107 \\
(0.028)\end{array}$ \\
\hline Three Additional Applications & $\begin{array}{r}0.008 \\
{[0.089]}\end{array}$ & & $\begin{array}{r}0.010 \\
(0.115)\end{array}$ \\
\hline Adjusted R Squared & -- & 0.199 & 0.205 \\
\hline N & 2,127 & 2,127 & 2,127 \\
\hline
\end{tabular}

Notes: Each equation also includes a constant term. Standard errors are in parentheses. Equations are estimated by WLS. All respondents who earned over $\$ 5,000$ in 1985 are included, regardless of full-time work status.

The mean of the dependent variable is 10.087 , and the standard deviation is .525 . 
Table 8

Log Earnings Regression Allowing the Effect of School-Average SAT to Vary with Parental Income, C\&B Pooled Sample of Male and Female Full-Time Workers

\begin{tabular}{|c|c|c|c|}
\hline \multirow[b]{3}{*}{ Variable } & \multicolumn{3}{|c|}{ Parameter Estimates } \\
\hline & $\begin{array}{l}\text { Basic Model: } \\
\text { No Selection } \\
\text { Controls } \\
\end{array}$ & $\begin{array}{c}\text { Matched } \\
\text { Applicant } \\
\text { Model* } \\
\end{array}$ & $\begin{array}{c}\text { Self- } \\
\text { Revelation } \\
\text { Model }\end{array}$ \\
\hline & & & \\
\hline School-Average SAT Score/100 & $\begin{array}{r}0.660 \\
(0.226)\end{array}$ & $\begin{array}{r}0.654 \\
(0.256)\end{array}$ & $\begin{array}{r}0.573 \\
(0.230)\end{array}$ \\
\hline Predicted Log(Parental Income) & $\begin{array}{r}0.871 \\
(0.255)\end{array}$ & $\begin{array}{r}0.964 \\
(0.278)\end{array}$ & $\begin{array}{r}0.830 \\
(0.258)\end{array}$ \\
\hline Predicted Log of Parental Income ${ }^{\star}$ School SAT Score/100 & $\begin{array}{r}-0.060 \\
(0.023)\end{array}$ & $\begin{array}{r}-0.068 \\
(0.026)\end{array}$ & $\begin{array}{r}-0.058 \\
(0.023)\end{array}$ \\
\hline OWn SAT Score/100 & $\begin{array}{r}0.029 \\
(0.005)\end{array}$ & $\begin{array}{c}-0.004 \\
(0.006)\end{array}$ & $\begin{array}{r}0.021 \\
(0.005)\end{array}$ \\
\hline Female & $\begin{array}{r}-0.395 \\
(0.014)\end{array}$ & $\begin{array}{r}-0.416 \\
(0.025)\end{array}$ & $\begin{array}{r}-0.388 \\
(0.013)\end{array}$ \\
\hline Black & $\begin{array}{r}0.017 \\
(0.030)\end{array}$ & $\begin{array}{c}-0.027 \\
(0.052)\end{array}$ & $\begin{array}{r}0.006 \\
(0.030)\end{array}$ \\
\hline Hispanic & $\begin{array}{r}-0.001 \\
(0.042)\end{array}$ & $\begin{array}{r}-0.115 \\
(0.118)\end{array}$ & $\begin{array}{r}-0.005 \\
(0.046)\end{array}$ \\
\hline Asian & $\begin{array}{r}0.209 \\
(0.034)\end{array}$ & $\begin{array}{r}0.279 \\
(0.071)\end{array}$ & $\begin{array}{r}0.190 \\
(0.036)\end{array}$ \\
\hline Other/Missing Race & $\begin{array}{r}-0.198 \\
(0.147)\end{array}$ & $\begin{array}{r}0.196 \\
(0.210)\end{array}$ & $\begin{array}{r}-0.203 \\
(0.144)\end{array}$ \\
\hline High School Top Ten Percent & $\begin{array}{r}0.055 \\
(0.024)\end{array}$ & $\begin{array}{r}0.094 \\
(0.022)\end{array}$ & $\begin{array}{r}0.058 \\
(0.024)\end{array}$ \\
\hline High School Rank Missing & $\begin{array}{r}0.003 \\
(0.038)\end{array}$ & $\begin{array}{r}0.039 \\
(0.061)\end{array}$ & $\begin{array}{r}-0.006 \\
(0.035)\end{array}$ \\
\hline Athlete & $\begin{array}{r}0.113 \\
(0.024)\end{array}$ & $\begin{array}{r}0.139 \\
(0.048)\end{array}$ & $\begin{array}{r}0.105 \\
(0.022)\end{array}$ \\
\hline Average SAT Score/ 100 of Schools Applied To & & & $\begin{array}{r}0.079 \\
(0.016)\end{array}$ \\
\hline One Additional Application & & & $\begin{array}{r}0.055 \\
(0.009)\end{array}$ \\
\hline Two Additional Applications & & & $\begin{array}{r}0.065 \\
(0.026)\end{array}$ \\
\hline Three Additional Applications & & & $\begin{array}{r}0.095 \\
(0.039)\end{array}$ \\
\hline Four Additional Applications & & & $\begin{array}{r}0.094 \\
(0.041)\end{array}$ \\
\hline Adjusted R Squared & 0.109 & 0.146 & 0.114 \\
\hline $\mathrm{N}$ & 14,239 & 6,335 & 14,239 \\
\hline
\end{tabular}

Notes: Each equation also includes a constant term. Standard errors are in parentheses, and are robust to correlated errors among students who attended the same institution. Equations are estimated by WLS.

"Applicants are matched by the average SAT score (within 25 point intervals) of each school at which they were accepted or rejected. This model includes 1,232 dummy variables representing each set of matched applicants. 
Table 9

Log Earnings Regressions using Net Tuition as School Quality Indicator, C\&B Pooled Sample of Male and Female Full-Time Workers

\begin{tabular}{|c|c|c|c|c|c|c|}
\hline \multirow[b]{3}{*}{ Vaniable } & \multicolumn{6}{|c|}{ Parameter Estimates } \\
\hline & \multicolumn{2}{|c|}{$\begin{array}{l}\text { Basic Models: } \\
\text { No Selection Controls }\end{array}$} & \multicolumn{2}{|c|}{$\begin{array}{c}\text { Matched Applicant } \\
\text { Models* }\end{array}$} & \multicolumn{2}{|c|}{$\begin{array}{c}\text { Self-Revelation } \\
\text { Models }\end{array}$} \\
\hline & 1 & 2 & 3 & 4 & 5 & 6 \\
\hline Log(Net Tuition) & $\begin{array}{r}0.100 \\
(0.018)\end{array}$ & $\begin{array}{r}0.722 \\
(0.322)\end{array}$ & $\begin{array}{r}0.059 \\
(0.031)\end{array}$ & $\begin{array}{r}1.021 \\
(0.409)\end{array}$ & $\begin{array}{r}0.050 \\
(0.019)\end{array}$ & $\begin{array}{r}0.792 \\
(0.319)\end{array}$ \\
\hline Predicted Log(Parental Income) & $\begin{array}{r}0.192 \\
(0.020)\end{array}$ & $\begin{array}{r}0.646 \\
(0.242)\end{array}$ & $\begin{array}{r}0.190 \\
(0.025)\end{array}$ & $\begin{array}{r}0.902 \\
(0.317)\end{array}$ & $\begin{array}{r}0.176 \\
(0.021)\end{array}$ & $\begin{array}{r}0.718 \\
(0.247)\end{array}$ \\
\hline Log(Net Tuition)*Predicted Log (Parental Income & & $\begin{array}{r}-0.062 \\
(0.033)\end{array}$ & & $\begin{array}{r}-0.097 \\
(0.043)\end{array}$ & & $\begin{array}{r}-0.075 \\
(0.033)\end{array}$ \\
\hline Own SAT Score/100 & $\begin{array}{r}0.029 \\
(0.005)\end{array}$ & $\begin{array}{r}0.029 \\
(0.005)\end{array}$ & $\begin{array}{r}-0.005 \\
(0.006)\end{array}$ & $\begin{array}{r}-0.005 \\
(0.006)\end{array}$ & $\begin{array}{r}0.019 \\
(0.005)\end{array}$ & $\begin{array}{r}0.019 \\
(0.005)\end{array}$ \\
\hline Female & $\begin{array}{r}-0.392 \\
(0.013)\end{array}$ & $\begin{array}{r}-0.390 \\
(0.013)\end{array}$ & $\begin{array}{r}-0.417 \\
(0.024)\end{array}$ & $\begin{array}{r}-0.416 \\
(0.024)\end{array}$ & $\begin{array}{r}-0.392 \\
(0.014)\end{array}$ & $\begin{array}{r}-0.390 \\
(0.014)\end{array}$ \\
\hline Black & $\begin{array}{r}0.030 \\
(0.027)\end{array}$ & $\begin{array}{r}0.031 \\
(0.028)\end{array}$ & $\begin{array}{r}-0.025 \\
(0.052)\end{array}$ & $\begin{array}{r}-0.029 \\
(0.052)\end{array}$ & $\begin{array}{r}0.004 \\
(0.028)\end{array}$ & $\begin{array}{r}0.004 \\
(0.029)\end{array}$ \\
\hline Hispanic & $\begin{array}{r}0.005 \\
(0.039)\end{array}$ & $\begin{array}{r}-0.001 \\
(0.040)\end{array}$ & $\begin{array}{r}-0.117 \\
(0.116)\end{array}$ & $\begin{array}{r}-0.127 \\
(0.117)\end{array}$ & $\begin{array}{r}-0.010 \\
(0.045)\end{array}$ & $\begin{array}{r}-0.018 \\
(0.046)\end{array}$ \\
\hline Asian & $\begin{array}{r}0.206 \\
(0.031)\end{array}$ & $\begin{array}{r}0.204 \\
(0.031)\end{array}$ & $\begin{array}{r}0.275 \\
(0.070)\end{array}$ & $\begin{array}{r}0.274 \\
(0.070)\end{array}$ & $\begin{array}{r}0.186 \\
(0.035)\end{array}$ & $\begin{array}{r}0.184 \\
(0.036)\end{array}$ \\
\hline Other/Missing Race & $\begin{array}{r}-0.188 \\
(0.147)\end{array}$ & $\begin{array}{r}-0.187 \\
(0.147)\end{array}$ & $\begin{array}{r}0.212 \\
(0.210)\end{array}$ & $\begin{array}{r}0.206 \\
(0.209)\end{array}$ & $\begin{array}{r}-0.202 \\
(0.147)\end{array}$ & $\begin{array}{r}-0.201 \\
(0.147)\end{array}$ \\
\hline High School Top Ten Percent & $\begin{array}{r}0.067 \\
(0.027)\end{array}$ & $\begin{array}{r}0.068 \\
(0.028)\end{array}$ & $\begin{array}{r}0.098 \\
(0.021)\end{array}$ & $\begin{array}{r}0.100 \\
(0.021)\end{array}$ & $\begin{array}{r}0.062 \\
(0.027)\end{array}$ & $\begin{array}{r}0.063 \\
(0.027)\end{array}$ \\
\hline High School Rank Missing & $\begin{array}{r}-0.002 \\
(0.035)\end{array}$ & $\begin{array}{r}-0.001 \\
(0.035)\end{array}$ & $\begin{array}{r}0.041 \\
(0.060)\end{array}$ & $\begin{array}{r}0.044 \\
(0.060)\end{array}$ & $\begin{array}{r}-0.008 \\
(0.035)\end{array}$ & $\begin{array}{r}-0.006 \\
(0.034)\end{array}$ \\
\hline Athlete & $\begin{array}{r}0.114 \\
(0.025)\end{array}$ & $\begin{array}{r}0.115 \\
(0.024)\end{array}$ & $\begin{array}{r}0.137 \\
(0.048)\end{array}$ & $\begin{array}{r}0.136 \\
(0.048)\end{array}$ & $\begin{array}{r}0.097 \\
(0.022)\end{array}$ & $\begin{array}{r}0.098 \\
(0.022)\end{array}$ \\
\hline Average SAT Score/100 of Schools Applied To & & & & & $\begin{array}{r}0.053 \\
(0.010)\end{array}$ & $\begin{array}{r}0.055 \\
(0.010)\end{array}$ \\
\hline One Additional Application & & & & & $\begin{array}{r}0.047 \\
(0.008)\end{array}$ & $\begin{array}{r}0.046 \\
(0.007)\end{array}$ \\
\hline Two Additional Applications & & & & & $\begin{array}{r}0.052 \\
(0.024)\end{array}$ & $\begin{array}{r}0.052 \\
(0.024)\end{array}$ \\
\hline Three Additional Applications & & & & & $\begin{array}{r}0.082 \\
(0.036)\end{array}$ & $\begin{array}{r}0.082 \\
(0.036)\end{array}$ \\
\hline Four Additional Applications & & & & & $\begin{array}{r}0.082 \\
(0.044)\end{array}$ & $\begin{array}{r}0.084 \\
(0.043)\end{array}$ \\
\hline Adjusted R Squared & 0.112 & 0.112 & 0.146 & 0.147 & 0.115 & 0.115 \\
\hline $\mathrm{N}$ & 14,239 & 14,239 & 6,335 & 6,335 & 14,239 & 14,239 \\
\hline
\end{tabular}

Notes: Each equation aiso includes a constant term. Standard errors are in parentheses, and are robust to correlated errors among students who attended the same institution.

Equations are estimated by WLS. Net fuition is average fuition minus average aid (see text).

*Applicants are matched by the average SAT score (within 25 point intervals) of each school at which they were accepted or rejected. This model includes 1,232 dummy variables representing each set of matched applicants. 
Table 10

Linear Probability Models for Class Rank, Graduation Probability, and Advance Degree Attainment; C\&B Pooled Sample of Men and Women

\begin{tabular}{|c|c|c|c|c|c|c|c|c|c|}
\hline \multirow[b]{3}{*}{ Variable } & Percent & e Rank in $\mathrm{Cle}$ & & \multicolumn{3}{|c|}{$\begin{array}{l}\text { Dependent Variable } \\
\text { Graduation }(1=y e s ; 0=\text { no }\end{array}$} & \multicolumn{3}{|c|}{ Advanced Degree (1=yes, $0=$ no) } \\
\hline & $\begin{array}{c}\text { Basic Moded: } \\
\text { No Selection } \\
\text { Controls } \\
\end{array}$ & $\begin{array}{l}\text { Matched } \\
\text { Applicant } \\
\text { Model* } \\
\end{array}$ & $\begin{array}{c}\text { Self- } \\
\text { Revelation } \\
\text { Model } \\
\end{array}$ & $\begin{array}{c}\text { Basic Model: } \\
\text { No Selection } \\
\text { Controls }\end{array}$ & $\begin{array}{l}\text { Matched } \\
\text { Applicant } \\
\text { Model* }\end{array}$ & $\begin{array}{c}\text { Self- } \\
\text { Revelation } \\
\text { Model } \\
\end{array}$ & $\begin{array}{c}\text { Basic Model: } \\
\text { No Selection } \\
\text { Controls } \\
\end{array}$ & $\begin{array}{l}\text { Matched } \\
\text { Applicant } \\
\text { Model }^{*}\end{array}$ & $\begin{array}{c}\text { Self- } \\
\text { Revelation } \\
\text { Model }\end{array}$ \\
\hline & 1 & 2 & 3 & 4 & 5 & 6 & 7 & .8 & 9 \\
\hline School-Average SAT Score/100 & $\begin{array}{r}-5.636 \\
(0.661)\end{array}$ & $\begin{array}{r}-7.825 \\
(0.636)\end{array}$ & $\begin{array}{r}-6.404 \\
(0.923)\end{array}$ & $\begin{array}{r}0.002 \\
\langle 0.015\rangle\end{array}$ & $\begin{array}{r}-0.016 \\
(0.015)\end{array}$ & $\begin{array}{r}0.007 \\
(0.018)\end{array}$ & $\begin{array}{r}0.069 \\
(0.007)\end{array}$ & $\begin{array}{r}-0.002 \\
(0.013)\end{array}$ & $\begin{array}{r}0.035 \\
(0.011)\end{array}$ \\
\hline Predicted Log(Parental income) & $\begin{array}{r}4.566 \\
(1.333)\end{array}$ & $\begin{array}{r}2.677 \\
(0.946)\end{array}$ & $\begin{array}{r}4.689 \\
(1.156)\end{array}$ & $\begin{array}{r}0.046 \\
(0.008)\end{array}$ & $\begin{array}{r}0.040 \\
(0.018)\end{array}$ & $\begin{array}{r}0.048 \\
(0.009)\end{array}$ & $\begin{array}{r}0.126 \\
(0.022)\end{array}$ & $\begin{array}{r}0.086 \\
(0.019)\end{array}$ & $\begin{array}{r}0.117 \\
(0.021)\end{array}$ \\
\hline OWn SAT Score $/ 100$ & $\begin{array}{r}5.914 \\
(0.375)\end{array}$ & $\begin{array}{r}5.958 \\
(0.517)\end{array}$ & $\begin{array}{r}5.841 \\
(0.391)\end{array}$ & $\begin{array}{r}0.024 \\
\{0.006\rangle\end{array}$ & $\begin{array}{r}0.026 \\
(0.005)\end{array}$ & $\begin{array}{r}0.025 \\
(0.006)\end{array}$ & $\begin{array}{r}0.052 \\
(0.007)\end{array}$ & $\begin{array}{r}0.051 \\
(0.004)\end{array}$ & $\begin{array}{r}0.048 \\
(0.007)\end{array}$ \\
\hline Female & $\begin{array}{r}7.795 \\
\langle 0.705\rangle\end{array}$ & $\begin{array}{r}8.616 \\
(1.138)\end{array}$ & $\begin{array}{r}7.735 \\
(0.702)\end{array}$ & $\begin{array}{r}0.000 \\
\langle 0.009\rangle\end{array}$ & $\begin{array}{r}-0.007 \\
(0.010)\end{array}$ & $\begin{array}{r}-0.001 \\
(0.009)\end{array}$ & $\begin{array}{r}-0.067 \\
(0.009)\end{array}$ & $\begin{array}{l}-0.067 \\
(0.010)\end{array}$ & $\begin{array}{r}-0.064 \\
(0.009)\end{array}$ \\
\hline Black & $\begin{array}{r}-11.375 \\
(1.649)\end{array}$ & $\begin{array}{r}-12.571 \\
(1.867)\end{array}$ & $\begin{array}{r}-11.359 \\
(1.650)\end{array}$ & $\begin{array}{r}-0.009 \\
\langle 0.021\rangle\end{array}$ & $\begin{array}{r}0.034 \\
(0.038)\end{array}$ & $\begin{array}{r}-0.008 \\
(0.021)\end{array}$ & $\begin{array}{r}0.131 \\
(0.027)\end{array}$ & $\begin{array}{r}0.127 \\
(0.028)\end{array}$ & $\begin{array}{r}0.126 \\
(0.027)\end{array}$ \\
\hline Hispanic & $\begin{array}{r}-3.510 \\
(3.395)\end{array}$ & $\begin{array}{r}-6.388 \\
(3.749)\end{array}$ & $\begin{array}{r}-3.527 \\
(3.223)\end{array}$ & $\begin{array}{r}-0.067 \\
\langle 0.031\rangle\end{array}$ & $\begin{array}{r}-0.111 \\
(0.076)\end{array}$ & $\begin{array}{r}-0.068 \\
(0.031)\end{array}$ & $\begin{array}{r}0.106 \\
(0.054)\end{array}$ & $\begin{array}{r}0.077 \\
(0.062)\end{array}$ & $\begin{array}{r}0.103 \\
(0.055)\end{array}$ \\
\hline Asian ' & $\begin{array}{r}-0.054 \\
(2.770)\end{array}$ & $\begin{array}{r}-3.309 \\
(1.861)\end{array}$ & $\begin{array}{r}-0.108 \\
(2.661)\end{array}$ & $\begin{array}{r}0.027 \\
\langle 0.017\rangle\end{array}$ & $\begin{array}{r}0.027 \\
(0.029)\end{array}$ & $\begin{array}{r}0.028 \\
(0.017)\end{array}$ & $\begin{array}{r}0.087 \\
(0.026)\end{array}$ & $\begin{array}{r}0.137 \\
(0.053)\end{array}$ & $\begin{array}{r}0.079 \\
(0.024)\end{array}$ \\
\hline Other/Missing Race & $\begin{array}{r}-10.957 \\
(2.148)\end{array}$ & $\begin{array}{r}-10.525 \\
(2.801)\end{array}$ & $\begin{array}{r}-11.216 \\
(2.175)\end{array}$ & $\begin{array}{r}-0.193 \\
(0.074)\end{array}$ & $\begin{array}{l}-0.177 \\
(0.151)\end{array}$ & $\begin{array}{r}-0.192 \\
(0.073)\end{array}$ & $\begin{array}{r}-0.062 \\
(0.031)\end{array}$ & $\begin{array}{r}-0.229 \\
(0.047)\end{array}$ & $\begin{array}{r}-0.064 \\
(0.032)\end{array}$ \\
\hline High School Top Ten Percent & $\begin{array}{r}9.566 \\
(1.343)\end{array}$ & $\begin{array}{r}9.753 \\
(1.637)\end{array}$ & $\begin{array}{r}9.322 \\
(1.382)\end{array}$ & $\begin{array}{r}0.050 \\
(0.009\rangle\end{array}$ & $\begin{array}{r}0.028 \\
(0.016)\end{array}$ & $\begin{array}{r}0.051 \\
(0.009)\end{array}$ & $\begin{array}{r}0.072 \\
(0.017\rangle\end{array}$ & $\begin{array}{r}0.064 \\
(0.031)\end{array}$ & $\begin{array}{r}0.071 \\
(0.018)\end{array}$ \\
\hline High School Rank Missing & $\begin{array}{r}3.711 \\
(0.912)\end{array}$ & $\begin{array}{r}3.262 \\
(1.059)\end{array}$ & $\begin{array}{r}3.655 \\
(0.927)\end{array}$ & $\begin{array}{r}0.045 \\
(0.016\rangle\end{array}$ & $\begin{array}{r}0.015 \\
(0.017)\end{array}$ & $\begin{array}{r}0.047 \\
(0.015)\end{array}$ & $\begin{array}{r}0.018 \\
(0.017)\end{array}$ & $\begin{array}{r}0.019 \\
(0.029)\end{array}$ & $\begin{array}{r}0.014 \\
(0.019)\end{array}$ \\
\hline Athlete & $\begin{array}{r}-1.293 \\
(0.818)\end{array}$ & $\begin{array}{r}-1.592 \\
(1,798)\end{array}$ & $\begin{array}{r}-1.103 \\
(0.867)\end{array}$ & $\begin{array}{r}0.063 \\
(0.014)\end{array}$ & $\begin{array}{r}0.022 \\
(0.012)\end{array}$ & $\begin{array}{r}0.063 \\
(0.013)\end{array}$ & $\begin{array}{r}0.006 \\
(0.019)\end{array}$ & $\begin{array}{r}0.008 \\
(0.029\rangle\end{array}$ & $\begin{array}{r}0.004 \\
(0.019)\end{array}$ \\
\hline Average SAT Score/100 of Schools Applied To & & & $\begin{array}{r}1,681 \\
(0,841)\end{array}$ & & & $\begin{array}{r}-0.007 \\
(0.005)\end{array}$ & & & $\begin{array}{r}0.043 \\
(0.012)\end{array}$ \\
\hline One Additional Application & & • & $\begin{array}{r}0.052 \\
(0.640)\end{array}$ & & & $\begin{array}{r}0.015 \\
(0.012)\end{array}$ & & & $\begin{array}{r}0.018 \\
(0.011)\end{array}$ \\
\hline Two Additional Applications & & & $\begin{array}{r}-1.436 \\
(0.843)\end{array}$ & & & $\begin{array}{r}0.015 \\
(0.009)\end{array}$ & & & $\begin{array}{r}0.034 \\
(0.013)\end{array}$ \\
\hline Three Additional Applications & & & $\begin{array}{r}-4,009 \\
(0,863)\end{array}$ & & & $\begin{array}{r}0.006 \\
(0,015)\end{array}$ & & & $\begin{array}{r}0.013 \\
(0.020)\end{array}$ \\
\hline Four Additional Applications & & & $\begin{array}{r}-7.507 \\
(1.344)\end{array}$ & & & $\begin{array}{r}-0.064 \\
(0.022)\end{array}$ & & & $\begin{array}{r}-0.002 \\
(0.020)\end{array}$ \\
\hline Adjusted R Squared & 0.181 & 0.232 & 0.185 & 0.023 & 0.099 & 0.024 & 0.087 & 0.120 & 0.089 \\
\hline $\mathbf{N}$ & 19,062 & 9,042 & 19,062 & 19,505 & 9.207 & 19,505 & 19,505 & 9,207 & 19,505 \\
\hline
\end{tabular}

Notes; Sample includes all survey respondents, regardless of fuli-time work status. The percentile rank in class regression excludes those who were missing grade point averages. The graduation regression counts as graduates only those students who graduated from the same C\&B school at which they first matriculated.

Each equation also includes a constant term. Standard errors are in parentheses, and are robust to correlated errors among students who attended the same institution. Equations are estimated by WLS.

*Applicants are matched by the average SAT score (within 25 point intervals) of each school at which they were accepted or rejected. This model includes 1,566 dummy variables representing each set of matched applicants. 
Appendix Table 1

School-Average SAT Score and Net Tuition of C\&B Institutions

\begin{tabular}{lcc}
\hline Institution & $\begin{array}{c}\text { School-Average } \\
\text { SAT Score in } 1978\end{array}$ & \begin{tabular}{c} 
Net Tuition (\$) \\
\hline Barnard College
\end{tabular} \\
Bryn Mawr College & 1210 & 3530 \\
Columbia University & 1370 & 3171 \\
Denison University & 1330 & 3591 \\
Duke University & 1020 & 3254 \\
Emory University & 1226 & 3052 \\
Georgetown University & 1150 & 3237 \\
Hamilton College & 1225 & 3304 \\
Kenyon College & 1246 & 3529 \\
Miami University (Ohio) & 1155 & 3329 \\
Northwestern University & 1073 & 1304 \\
Oberlin College & 1240 & 3676 \\
Pennsylvania State University & 1227 & 3441 \\
Princeton University & 1038 & 1062 \\
Rice University & 1308 & 3613 \\
Smith College & 1316 & 1753 \\
Stanford University & 1210 & 3539 \\
Swarthmore College & 1270 & 3658 \\
Tufts University & 1340 & 3122 \\
Tulane University & 1200 & 3853 \\
University of Michigan (Ann Arbor) & 1080 & 3269 \\
University of North Carolina (Chapel Hill) & 1110 & 1517 \\
University of Notre Dame & 1080 & 541 \\
University of Pennsylvania & 1200 & 3216 \\
Vanderbilt University & 1280 & 3266 \\
Washington University & 1162 & 3155 \\
Wellesley College & 1180 & 3245 \\
Wesleyan University & 1220 & 3312 \\
Williams College & 1260 & 3368 \\
Yale University & 1255 & 3541 \\
& 1360 & 3744 \\
\hline & & \\
\hline
\end{tabular}

Notes: The school-average SAT scores were obtained from HERI, and pertain to freshmen. Net tuition for 1970 and 1980 was calculated by subtracting the average aid awarded to undergraduates from the sticker price tuition, as reported in the 11th and 12th editions editions of American Universities and Colleges. The 1976 net tuition was interpolated from the 1970 and 1980 net tuition, assuming an exponential rate of growth. 
Appendix Table 2

Regression Predicting the Natural Log of Parental income, C\&B Sample

\begin{tabular}{|c|c|c|}
\hline Variable & $\begin{array}{r}\text { Parameter } \\
\text { Estimate }\end{array}$ & $\begin{array}{r}\text { Standard } \\
\text { Error } \\
\end{array}$ \\
\hline Years of Father's Education & 0.067 & 0.003 \\
\hline Years of Mother's Education & 0.031 & 0.003 \\
\hline Mother's Education Missing & 0.550 & 0.096 \\
\hline Father's Education Missing & 0.915 & 0.085 \\
\hline Father's Occupation Missing Father's Education & 0.015 & 0.004 \\
\hline Mother's Occupation Missing "Mother's Education & 0.007 & 0.005 \\
\hline Father Clerical Occupation & 0.567 & 0.097 \\
\hline Father Management Consultant & 0.678 & 0.168 \\
\hline Father Sales & 0.669 & 0.044 \\
\hline Father Social Work & 0.563 & 0.283 \\
\hline Father Communications & 0.790 & 0.129 \\
\hline Father Policeman & 0.503 & 0.182 \\
\hline Father Financial Services & 0.813 & 0.048 \\
\hline Father Engineer & 0.808 & 0.042 \\
\hline Father Computer Occupation & 0.564 & 0.154 \\
\hline Father Physician & 0.839 & 0.047 \\
\hline Father Religious Worker & 0.132 & 0.069 \\
\hline Father Social Sciences & 0.695 & 0.096 \\
\hline Father Primary or Secondary Teacher & 0.549 & 0.047 \\
\hline Father Post-Secondary Teacher & 0.466 & 0.050 \\
\hline Father Writer, Arts, etc. & 0.670 & 0.063 \\
\hline Father Top Government position & 0.897 & 0.220 \\
\hline Father Lawyer or Judge & 0.819 & 0.049 \\
\hline Father Health Occupation & 0.640 & 0.054 \\
\hline Father Math or Science Occupation & 0.678 & 0.059 \\
\hline Father Military & 0.531 & 0.056 \\
\hline Father Service Occupation & 0.521 & 0.061 \\
\hline Father Agriculture & 0.333 & 0.062 \\
\hline Father Businessman (general) & 0.752 & 0.043 \\
\hline Father Other Occupation & 0.606 & 0.042 \\
\hline Father Management Occupation & 0.886 & 0.040 \\
\hline Father Skilled Worker & 0.577 & 0.045 \\
\hline Father Semi-skilled Worker & 0.409 & 0.050 \\
\hline Father Unskilled Worker & 0.339 & 0.063 \\
\hline Father's Occupation Missing & 0.376 & 0.082 \\
\hline Mother Clerical Occupation & -0.098 & 0.019 \\
\hline Mother Management Consultant & -0.393 & 0.654 \\
\hline Mother Sales & -0.090 & 0.039 \\
\hline Mother Social Work & 0.032 & 0.118 \\
\hline Mother Communications & 0.009 & 0.142 \\
\hline Mother Policeman & 0.388 & 0.341 \\
\hline Mother Financial Services & .0 .004 & 0.054 \\
\hline Mother Engineer & -0.078 & 0.188 \\
\hline Mother Computer Occupation & 0.149 & 0.222 \\
\hline Mother Physician & 0.061 & 0.097 \\
\hline Mother Religious Worker & -0.477 & 0.180 \\
\hline Mother Social Sciences & -0.031 & 0.071 \\
\hline Mother Primary or Secondary Teacher & -0.045 & 0.019 \\
\hline Mother Post-Secondary Teacher & -0.062 & 0.055 \\
\hline Mother Writer, Arts, etc. & -0.125 & 0.039 \\
\hline Mother Top Government Position & 0.077 & 0.308 \\
\hline Mother Lawyer or Judge & -0.018 & 0.168 \\
\hline Mother Health Occupation & -0.081 & 0.023 \\
\hline Mother Math or Science Occupation & -0.004 & 0.150 \\
\hline Mother Service Occupation & -0.201 & 0.069 \\
\hline Mother Agriculture & -0.043 & 0.281 \\
\hline Mother Business (general) & 0.008 & 0.053 \\
\hline Mother Other Occupation & -0.077 & 0.019 \\
\hline Mother Management Occupation & 0.025 & 0.038 \\
\hline Mother Skilled Worker & -0.140 & 0.052 \\
\hline Mother Semi-skilled Worker & -0.178 & 0.039 \\
\hline Mother Unskilled Worker & -0.299 & 0.070 \\
\hline Mother's Occupation Missing & -0.054 & 0.081 \\
\hline R Squared & 0.342 & \\
\hline$N$ & 10,525 & \\
\hline
\end{tabular}

Notes: Baseline categories are "father not working" and "mother not working." The equation also includes a constant term. The primary source of parental occupation is the C\&B institutional file, which is based on students' college applications Parental Income information is from responses to the Student Descriptive Questionnaire (SDQ), administered by the Educational Testing Service (ETS) when the studerts took the SAT. Mother's and father's education are based on responses to the C\&B survey: "During your senior year in high school, what was the highest level of education your mother (father) had attained?" Students' responses to the CIRP freshmen questionnaire were used to fill in parental occupation and education if these variables were unavailable from the other sources 